\title{
Is Financial Regulation Good or Bad for Real Estate Companies? - An Event Study
}

\author{
Martin Hoesli ${ }^{1,2} \cdot{\text { Stanimira } \text { Milcheva }^{3} \text { (D) }}^{\text {. }}$ \\ Alex Moss 4
}

Published online: 12 October 2017

(C) The Author(s) 2017. This article is an open access publication

\begin{abstract}
This study investigates how three regulatory reforms undertaken in the aftermath of the global financial crisis have affected returns of real estate companies. The three reforms are aimed at regulating different segments of the market - Basel III targets banks, and could restrict the availability of bank debt to the sector; the Alternative Investment Fund Management Directive (AIFMD) targets funds, which could increase compliance costs and reduce the potential investor pool; the European Market Infrastructure Regulation (EMIR) is aimed at derivative trading and could impact the cost of debt capital. We employ an event study methodology using daily stock returns of real estate companies and identify the regulatory events through news published in major international financial newspapers and news agencies. Our results show different responses across the three regulations. For Basel III we find support for the regulatory burden hypothesis of the bank lending channel for small real estate firms and firms with low debt-to-equity ratios as they cannot diversify their funding sources. The direct regulatory effect as tested using AIFMD announcements supports the profitbased reaction hypothesis for large firms. We also show that the news have asymmetric effects with tighter regulation news more frequently leading to significant responses in average abnormal returns (AARs) than loosening regulation news.
\end{abstract}

Keywords Financial market regulation - Basel III · AIFMD · EMIR · Event study · Listed real estate companies $\cdot$ CAPM

Stanimira Milcheva

s.milcheva@ucl.ac.uk

1 University of Geneva, Geneva, Switzerland

2 University of Aberdeen, Aberdeen, UK

3 University College London, The Bartlett, UCL, 1-19 Torrington Place, London WC1E 7HB, UK

4 University of Reading and Consilia Capital, London, UK 
JEL Classification $\mathrm{G} 14 \cdot \mathrm{G} 28 \cdot \mathrm{R} 30$

\section{Introduction}

In the aftermath of the global financial crisis (GFC) regulators tried to strengthen the resilience of the financial system and reduce systemic risks by improving the existing financial market regulations and putting new regulations in place. Some of the main regulatory reforms which have been introduced at the international level include Basel III, the Alternative Investment Fund Management Directive (AIFMD) and the European Market Infrastructure Regulation (EMIR). Whereas Basel III extends the regulations for depository institutions imposed by Basel II, the AIFMD is a new regulation that targets non-UCITS funds, which are regarded as alternative funds including private equity, hedge funds and real estate funds in order to increase the transparency of that market and better protect investors. The EMIR is another regulation whose aim is to increase the transparency of the over-the-counter (OTC) derivative markets.

The above regulations potentially could have strong direct or indirect effects on real estate companies. We could observe indirect effects stemming from Basel III given the high credit intensity of direct real estate as an asset class. Real estate companies purchase assets for investment purposes and in order to do so, they operate with high leverage - tapping into the debt markets. Bank credit is still the predominant source of financing for listed real estate companies investing in income-producing properties. Hence, companies strongly relying on bank loans can be affected if banks are subject to new regulations. This could happen through the bank lending channel (Gambacorta 2005; Milcheva 2013a). Banks may change the funding costs for real estate companies in response to the financial regulation and this can have effects on the valuation of the companies and hence their performance. Other types of regulation such as AIFMD target directly real estate companies and funds. They can be associated with increases in the cost of compliance or increases in operating costs therefore having a direct impact on the cash flows of real estate companies. Finally, given that real estate is a lumpy asset requiring long-term financing, real estate companies may decide to hedge interest rate risk using derivative products. The instruction of EMIR could thus have strong effects on real estate companies which are trading such securities and may have indirect effects on the cost of hedging and hence their performance.

Overall, there is scarce research assessing the impacts of the recent financial market reforms. The lack of empirical research in this area thus far is due to the dearth of data and the uncertainty surrounding some of the regulatory reforms. Most of the research that has assessed the relationship between regulation and asset prices has looked at the role of bubbles on financial institutions. Schleifer and Vishny (2011) discuss the effect of real estate bubble bursts on leveraged financial institutions and a subsequent deleveraging and fire sales. Crowe et al. (2013) argue that real estate booms which are financed through credit and involve leverage would lead to more pronounced regulatory actions associated with macroprudential regulations. Allen and Carletti (2013) develop a model of real estate pricing in two regimes accounting for borrowing and agency problems and use it to analyze the effects of macroprudential policies. Some of those regulatory measures include loan-to-value (LTV) restrictions and capital requirements. Basett and Blake Marsh (2016) look specifically at the effects of financial market regulations on banks with high exposure to commercial real estate loans. They 
show that such banks reduce the provision of commercial real estate lending and substitute it with housing lending when faced with higher regulation. Such macroprudential regulation can affect the bank behavior and hence real estate loan provision. Cronin and McQuinn (2016) show for the Irish housing market that regulations targeting LTV ratios for bank loans would lead to higher demand for rental accommodation and higher rents.

Overall, we see that there is a relationship between asset prices and in particular real estate prices and regulation - but most of it from a macroeconomic perspective. Although we still cannot assess the long-term welfare implications without awaiting the full implementation of the regulations, this study provides a first assessment of the contemporaneous effects of financial regulations on the listed real estate sector. Our main focus is on analyzing the impact of regulation on the value of equity as well as market risk of listed real estate companies in selected European countries with well-developed listed real estate markets (France, Germany and the U.K.). We assess whether announcements about regulatory reforms post-GFC affect those companies and what are the channels of transmission of the news. We assess the channels through which regulatory news affect the performance of listed real estate companies distinguishing between type, size, leverage, and location of the companies.

As our focus will be on news about financial regulation, we use an event study methodology to assess the implications of stock returns. Event studies have traditionally been used to evaluate the impacts of regulatory news and go back to Schwert (1981). They have mainly been used to assess the effects of changes in the market value of equity since it is most sensitive to information given the residualclaim nature for investors of the asset class. More recently, this methodology has been applied to assess the impacts of policy and regulatory actions associated with the GFC. For example, Schäfer et al. (2015) look at the effects of press announcements of major country-level banking regulations post-GFC on stock returns in Germany, Switzerland, the U.K. and the U.S. They find that the largest implications for returns stem from the Dodd-Frank reform enacted in the U.S. and in particular from the Volcker rule. Bongini et al. (2015) conduct a case study to investigate the effects associated with the publication of a list of systemically important financial institutions (SIFI) and new regulation for too-big-to-fail (TBTF) banks. They find that only the returns of institutions which are poorly capitalized respond significantly negatively to the announcements. Fratianni and Marchionne (2013) use an event study to assess the effects of government intervention announcements to inject capital in troubled banks and the banking industry as a whole following the GFC. They find that the effects of announcements to help individual banks have negative effects on the stocks of those banks. Announcements about government support for the entire financial sector have however no significant effects on bank valuations when controlling for time and bank fixed effects. The authors conclude that such announcements were either not credible or not appropriate to address the problems in the financial markets. Veronesi and Zingales (2010) find that the effect of the Paulson Plan on the valuation of banks had a positive effect decreasing the probability of bankruptcy, providing benefits for bondholders of major investment banks. Georgiadis and Graeb (2016) show that announcements about the asset purchase program by the 
European Central Bank (ECB) have significant effects on equity indices across different countries, government bond yields and exchange rates.

The use of event studies requires the correct identification of the regulatory events or event periods. An investigation of large-scale financial market regulations such as Basel can present a challenge since the reform is subject to a complex negotiation process over several years and has been phased out several times already. Such large-scale regulations involve a lot of parties, such as consultants, lawyers, politicians, governments, regulated institutions (i.e., banks and fund managers), investors, who meet to discuss the reforms which can affect the likelihood of one or another outcome. This means that financial market participants continuously adjust their expectations with regards to the regulation following unexpected announcements. Therefore, markets would react only if the outcomes differ from their expectations. If, for example, there is news about regulation becoming more lax, markets would respond positively, and vice versa. However, the reforms can be a predictable process and could already have been reflected in the prices of stocks prior to the official announcement. Therefore, we want to identify the true impact of the regulatory event, not when the reform has officially been introduced, but when, for the first time, news about the regulatory reform has become available.

We follow the methodologies in O'Hara and Shaw (1990) and Schäfer et al. (2015) to identify events by looking at major newspapers. In particular, we follow a three-step approach. First, we search for news containing the name of the regulatory reform in the Financial Times. We select as news associated with Basel III those articles which have been published on the front page. The reason is that Basel III is a major international financial market reform and information representing real news should appear as a headline of a major international financial newspaper. Regarding the identification of the AIFMD and EMIR, a front page search is problematic, as these are more specific regulations which do not necessary feature on front pages. For them, we consider articles across all pages which contain the name of the regulation. Second, the ultimate choice of the events is made by screening all identified articles and assessing if it is considered news or not. Third, we double check if the dates identified feature in other media such as other newspapers, regulatory bodies' websites or news agencies (i.e., Bloomberg).

Our results show large differences across the three regulations. Basel III and EMIR have overall small aggregate effects on the performance as they do not directly regulate real estate companies. However we find some support for the regulatory burden hypothesis of the bank lending channel. We document that the banking regulation negatively affects small firms and firms with low debt-toequity ratios. This may suggest that the strongest effect is observed for firms who cannot diversify their funding sources and are thus hit strongest by Basel III. The direct channel through the AIFMD supports rather the profit-based reaction hypothesis. Mainly large firms are affected positively by the regulation which can be due to identified regulatory arbitrage opportunities for real estate companies if they do not have to comply with AIFMD. Overall, we see that different regulation can have opposite effects on companies and it is important to look at them separately as well as assess the impacts of tighter regulation news and 
loosening regulation news separately. We find strong evidence for asymmetric effects with negative news more frequently leading to significant responses.

\section{Effects of Regulatory Reforms}

\section{Hypotheses}

The effect of the regulations can lead to three possible outcomes - an overall positive reaction to the news, an overall negative reaction, or no significant reaction. Similar to Bongini et al. (2015), we identify three hypotheses which are graphically presented in Fig. 1. The profit-based reaction hypothesis assumes a positive market reaction due to the benefits of regulation associated with an increase in welfare and decrease of the price of capital due to less systemic risk and uncertainty. Regulation can prevent systemic events and contagion and lower the connectedness among financial institutions thus making them more resilient to downturns. For Basel III, for example, if banks are more tightly regulated, market participants can see this as an improvement in financial stability and hence reduce the cost of systemic risk. This can have positive effects on funding costs and may lead to banks offering cheaper financing in the end.

The opposite effect can be associated with the regulatory burden hypothesis. It assumes that financial regulation is rather a regulatory burden because it can, for instance, increase the cost of risk diversification, as well as operating and compliance costs, or reduce the number of eligible investors. In the case of Basel III, regulatory capital requirements can be such heavy covenants that all the wealth effects noted above would quickly dissipate. An increase in compliance costs can be outsourced to final borrowers and alter their funding costs as a result.

Finally, regulation may not have any noticeable impact. This is in line with the irrelevance hypothesis which assumes that markets do not expect regulation to have an

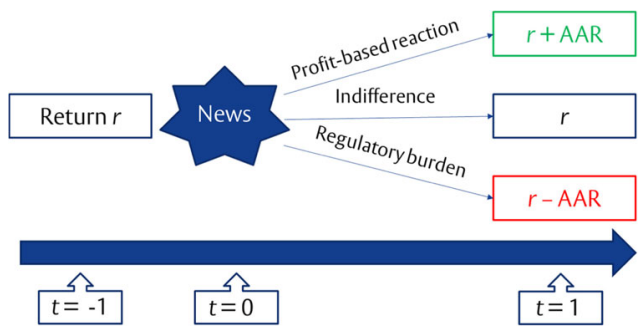

Note: Return $r$ is the return in the period just before the announcement, $t=-1$. In the current period, $t=0$, there is news about tighter financial market regulation. We have three hypotheses in the outcome of the returns in the next period, $t=1$. The return $r$ can be higher, increasing by the value of the average abnormal return (AAR) in line with the profit-based reaction; it can fall by AAR in line with the regulatory burden hypothesis or it can remain unchanged, in line with the indifference hypothesis.

Fig. 1 Hypotheses for the responses to news about tighter financial market regulation. Note: Return $r$ is the return in the period just before the announcement, $t=-1$. In the current period, $t=0$, there is news about tighter financial market regulation. We have three hypotheses in the outcome of the returns in the next period, $t=1$. The return $\mathrm{r}$ can be higher, increasing by the value of the average abnormal return (AAR) in line with the profit-based reaction; it can fall by AAR in line with the regulatory burden hypothesis or it can remain unchanged, in line with the indifference hypothesis 
impact on the company of interest as the new regulation is not considered a dramatic regulatory change. For the example of Basel III, markets may already believe that there may be alternative and cheap sources of funding such as debt issuance or alternative providers of loans, thus no wealth effect can be tied to the new regulation. This is associated with the possibility of regulatory arbitrage, when financial institutions manage to sustain their operations escaping tighter regulation. A tightening in the banking regulation creates a window of opportunity for 'shadow banks' to take on market share by providing loans. If regulation is perceived as too tight, traditional financial intermediaries can shift funds off balance sheets towards the less regulated financial sector through special purpose vehicles (SPVs) in a similar fashion as they did prior to the GFC.

Kroszner and Strahan (2011) argue that the Basel reforms "encouraged firms outside the regulatory umbrella to engage in activities traditionally done by those under the umbrella" leading to the emergence of balance sheets of unregulated banks. Kim and Mangla (2012) explain the excessive flow of investment into the shadow sector prior to the financial crisis with too tight banking regulation. An increased interconnection between the shadow and the traditional financial sector has been observed in both the euro area and the U.S. with a significant share of financing coming from the shadows (Bakk-Simon et al. 2012). Therefore, despite the potential negative impact on funding costs for bank lending, large companies could be able to access alternative sources of debt capital (through the issuance of corporate bonds, or other non-bank lenders) reducing the impact of Basel III. Milcheva (2013b) discusses the effects of regulatory announcements on the housing and stock markets looking at the effect of regulatory arbitrage. The author finds that regulatory arbitrage via the U.S. securitized sector may enhance the cross-country reallocation of capital from housing markets towards equity markets thereby leading to higher equity prices and lower house prices. In this paper, regulatory arbitrage may be a way of reducing the regulatory burden for regulated financial institutions and prohibit changes in the price of the funding costs.

\section{Basel III and the Bank Lending Channel}

The main objective of Basel III is to avoid future bank failure and systemic risk in the wider economy by requiring depository financial institutions to hold more capital against expected losses or to change their assessment of risk. The third instalment of the Basel Accords was developed as a response to the problems associated with banking regulation revealed by the GFC between 2010 and 2011 and is being phased

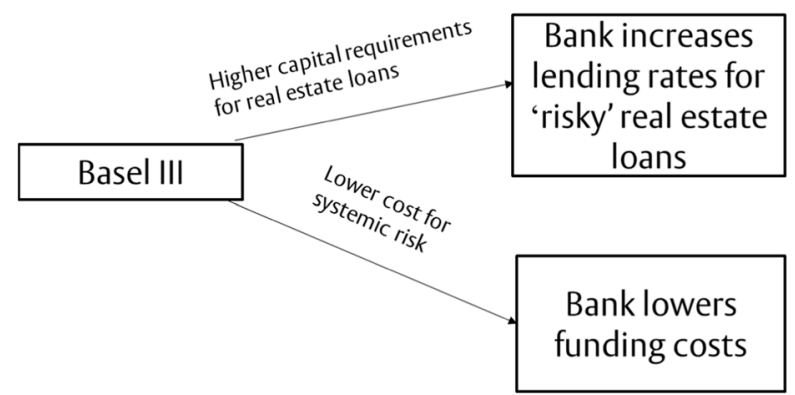

Fig. 2 Basel III and the bank lending channel 
in until March 2019. Pillar I of the regulation tightens the definition of what can be included in the calculation of bank capital and tries to make the methodology of calculating risk-weighted assets more sensitive to risks.

Albeit regulating banks, Basel III can have indirect effects on listed real estate companies through the bank lending channel. The channel is presented in Fig. 2. Basel III regulates banks with the aim to make them more resilient to downturns and prevent global systemic effects. To do this, one can say that Basel III poses tighter regulatory capital requirements for certain types of real estate loans. Therefore, the bank lending channel can lead to higher or lower credit provision by banks depending on which of the above effects of the regulation prevails. On the one side, the loan provision to real estate companies can be negatively affected, reducing the amount of bank credit available due to a change in the risk assessment of real estate loans under Basel III as compared to Basel II. For example, one change is the risk weighting for a new category of loans - highvolatility commercial real estate (HVCRE) loans - which receive a risk weighting of $150 \%$ compared to $100 \%$ previously under Basel II. A loan is classified as an HVCRE loan when it finances the acquisition, development, or construction of real property ${ }^{1}$ mostly with loan-to-value (LTV) ratios above $80 \%$. As a result of the higher weighting, banks will end up with higher regulatory capital requirements of $12 \%$ instead of currently $8 \%$ when providing this type of loans and they may decide to reduce the loan provision to developers and real estate companies.

Another change is related to the risk assessment of project loans which could face a risk weight of up to $250 \%$. Project loans are one of the main ways large scale real estate projects and infrastructure projects are financed. Furthermore, Basel III increases the risk weight of mortgage servicing rights (MSRs) which are generated when banks originate mortgages. As a result, banks can decide to sell off the MSRs to other non-bank companies to manage them instead of keeping them on their balance sheets. This may increase the costs for them and these costs can be outsourced to the mortgage borrowers. Given higher risk weights for certain types of real estate loans, banks may decide to decrease the amount of lending to real estate companies or may increase the borrowing costs. In this case, we would expect a negative effect on the returns of real estate companies. The reason is that markets perceive the regulation as negative either through an increase in the cost of debt or through a decrease in the quantity of debt. This is in line with the regulatory burden hypothesis.

On the other hand, market participants can perceive regulation as a necessary evil, which in the long run will lead to less interconnectedness between financial institutions and less systemic risk. This in turn may result in a more efficient and stable financial system, and reduce the overall funding costs. If this is the case, we would expect a positive effect on the returns, in line with the profit-based reaction hypothesis. Therefore we would expect Basel III to affect more strongly real estate companies which have high loan-to-value (LTV) ratios. In addition, companies which rely more heavily on bank finance may be more strongly affected. We also

\footnotetext{
${ }^{1}$ Exempt from the HVCRE classification are loans that finance the acquisition, development or construction of one- to four-family residential properties, real property that would qualify as community development investments, or loans to business or farms with gross revenues of $\$ 1$ million or more.
} 
may observe that small and large firms are affected differently. Large companies may be less negatively affected by the regulation as they will be able to offset higher bank funding costs by tapping into alternative sources of funding such as issuing debt, a secondary equity issuance, or junior sources of funding by other financial institutions. We can observe some crowding out of small companies which may lose competitiveness.

\section{AIFMD and the Direct Fund Channel}

While Basel III is a regulatory reform not directly affecting real estate companies, the AIFMD would have a direct effect on real estate firms which are operated as alternative funds - the direct fund channel. Talks about the AIFMD started in 2009 with the directive being published on July 1, 2011. The directive had to be adopted into the national laws by July 22, 2013. The AIFMD introduces for the first time a harmonized European regulatory regime for managers of Alternative Investment Funds (AIFs). The AIFMD defines an AIF as any collective investment scheme which raises capital from a number of investors with a view to investing that capital in accordance with a defined investment policy. Thus, the definition of an AIF is extremely wide and captures many open-ended and closed-ended listed and unlisted real estate funds. It may also apply to a subset of global real estate investment trusts (REITs) and property companies depending on the decisions by national regulators as well as on the decision of the company's management. While AIFMD is a European-wide regulation - it is up to the discretion of the national authorities how they will proceed with it. Therefore, we may observe a different approach to classifying companies into AIFs across the countries. The approach adopted in countries like the U.K., Germany and France is on a case-bycase basis. Whether a listed real estate company qualifies as an AIF would depend on the purpose and the investment strategy of the company.

The impact of the AIFMD on the European listed real estate companies is direct and would affect their operations making them either more efficient or increasing the compliance costs which may lead to more or less competition on the market for funds. Thus, the effects can be either positive or negative. The profit-based reaction hypothesis can be associated with the potential benefits associated with 'passporting', i.e., funds that have obtained a 'passport' would be allowed to operate across Europe. However, AIFMD could also be associated with regulatory burdens for real estate investment vehicles and could therefore redefine existing boundaries in the real estate sector. On the one hand, given the high compliance costs, the AIFMD may crowd out some nonEuropean Union (EU) REITs despite their interest in the EU market. As a result, this may lead to a significantly smaller number of players in the European market if non-EU managers together with some EU managers exit the EU market. Moreover, the uncertainty for non-EU investors surrounding the new legislation may deter investment in REITs which are classified as AIFs. In particular, this can be the case for Chinese investors who face restrictions for holdings in foreign funds.

On the other hand, the AIFMD may encourage the passive rather than the active model with REITs adopting the structure of a fund rather than that of an actively managed real estate business with implications for the financing of real estate development and infrastructure projects. Moreover, whether a listed real estate company is qualified as an AIF or not could also determine the underwriting status for insurance companies, pension funds 
and banks and lead to changes in the shareholders' structure of REITs. In Belgium, for example, the majority of REITs had to seek shareholder approval to adopt a new corporate status that legally separates them from funds, thereby avoiding the additional regulatory constraints and higher costs that AIFMD would have imposed. The regulatory ignorance hypothesis suggests that investors may not perceive the AIFMD regulation as relevant. That can be the case if certain property companies are not be classified as AIFs hence they are unaffected by the regulation. One would therefore expect the AIFMD regulation to have different effects across European countries and across companies depending on how it is implemented in each country and across types of companies. In addition, we could find differences between small and large real estate companies. Large companies may be less negatively affected by the regulation as they will be able to offset higher compliance costs more easily due to economies of scale. We can observe some crowding out of small companies which may lose competitiveness.

\section{EMIR and the Hedge Channel}

If a REIT falls under the AIFMD regulation, it will be classified as a financial entity becoming subject to the EMIR. EMIR regulates any entity classified as a 'financial counterparty' which includes any real estate vehicle which is an AIF under the AIFMD and subjects the real estate vehicle to mandatory clearing of derivative transactions. This can have negative implications for the company as it may be required to hold extra cash collateral with a central counterparty whenever it uses swap arrangements. The effect of the EMIR regulation can be particularly pronounced for real estate companies and funds as they would hedge the mortgage rates of longterm real estate loans against floating interest rates. As a result, small companies may decide not to hedge against those risks and this can make them riskier or lead to an increase in the funding costs (see Fig. 3). The effect on the real estate companies is thus indirect through the 'hedge' channel. If companies rely on hedging activities, then they can be affected as they would need to comply with EMIR. Larger companies instead may not experience any significant effect as they will more easily find the resources to provide additional collateral.

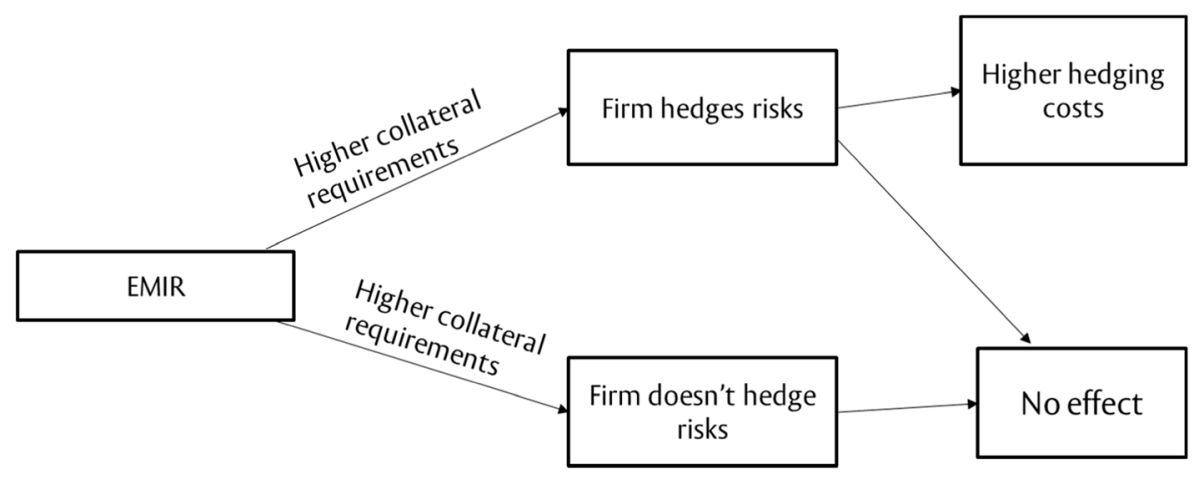

Fig. 3 EMIR and the hedge channel 


\section{Methodology and Data}

\section{Selection of Events}

In order to measure the regulatory impacts, we look at announcements associated with regulatory changes. Thereby, we want to account for the fact that the majority of the regulatory events do not involve a single well-defined announcement and are not associated with a single date. Large regulations such as Basel III rather involve a series of smaller announcements which can gradually affect listed real estate companies. ${ }^{2}$

There are several ways to collect information on announcements associated with regulatory changes. One way is to look at reports by regulatory bodies and their representatives, such as the European Commission (EC), the European Securities and Markets Authority (ESMA), and the Basel Committee on Banking Supervision (BCBS). However, using such sources of information only can leave us with incorrect identification of events if market participants have already priced the news prior to the official announcement of the regulatory body. Therefore, we want to identify the true regulatory event, not when the reform has officially been introduced, but when, for the first time, news with regards to the regulation has become available. We use a common way of identifying events by using the editor process of news agencies such as the Wall Street Journal and Financial Times. This approach has been used in previous studies such as O'Hara and Shaw (1990) and Schäfer et al. (2015).

The selection of the event dates in this paper consists in several steps for the purpose of ensuring the right identification of events. In the first step, we search for events in the paper edition of the Financial Times (FT) UK and FT Europe using ProQuest. The search is conducted using the full name of the regulation as a keyword to sort out potential articles. For Basel III, we select all articles containing the word 'Basel III' which feature on the front page. A similar selection process has been applied by Schäfer et al. (2015). The reason is that Basel III is the major international financial market reform in recent years and information representing real news should appear as a headline of a major international financial newspaper. Regarding the identification of the AIFMD and EMIR, a front page search is problematic, as these are more specific regulations which do not necessary feature on front pages because they affect specific industries only and are conducted on a smaller scale. For them, we conduct a keyword search of articles across all pages.

After narrowing down the potential pool of events, we read each article and make a decision if it is real news or just a commentary not announcing anything new. In this process we look for keywords which may indicate some new information associated with amendments to the regulations. For example, there can be an interview for a regulator who announces that the regulation will be tighter than expected. If an article reports a past event, such as a meeting of the Basel committee, we look up when the meeting was and whether there were any previous news associated with it. In a next step, we double check if the news has been announced on that date and in this newspaper first or features somewhere else earlier. The way we account for it is by searching in the Bloomberg news database

\footnotetext{
$\overline{2}$ Binder (1985) analyzes major changes in regulatory constraints in the U.S. and finds that most regulatory changes are already anticipated in the stock returns.
} 
1 month prior to the identified FT article for similar news. As Bloomberg cover a wide range of sources including newspapers, we can be confident that it accounts for major news.

Moreover, during the Bloomberg search, we account for the exact time at which the news was first published online as it can be the case that the paper edition has a delay and the news first features online. This is important as some articles can be published after stock markets have closed, so market participants cannot account for the news on that day. If this is the case, we choose the following day as the event date. The final step is to control for other news/ events which have taken place on the same day as the regulation news. For this purpose, we screen the front page of the paper edition of the FT Europe for each of the dates we have identified through the above procedure. We are looking for events which can also have strong effects on listed real estate companies and major economic news (e.g., the Greek crisis or the ECB policy). The final event dates are presented in Table 1. Along with the event date, we include the title of the article, a short description of the event, the source of the news, the publication date of the news as well as the expected effect on returns following the news - tighter regulation news or loosening regulation news.

Given the international nature of the reforms and the large number of parties involved in the consultations, information is less likely to remain confidential. For this purpose, we choose an event window of 3 days instead of just 1 day allowing for market anticipation and delayed reaction. Schäfer et al. (2015) also choose an event window of 3 days - 1 day before the announcement, the day of the announcement when the article is published and 1 day after the announcement.

\section{Market Data}

We use daily stock prices of real estate companies sourced from Thomson Datastream. The focus on European countries is explained by the fact that the regulatory reforms we study affect predominately European-domiciled companies. The countries in our sample include France, Germany and the U.K. as they have the largest listed real estate markets. Figure 4 shows daily equally-weighted returns of the 15 largest real estate companies from UK, Germany and France from January 1, 2009 to April 1, 2015. ${ }^{3} \mathrm{We}$ can see that in some days during the GFC and again in May-July 2010 and the second half of 2011 returns show considerably higher or lower values as compared to returns during the rest of the sample period. Those are also the periods in which most of the regulatory announcements have happened.

With regards to the market returns, we use a global market index in the baseline estimations in order to exclude the possibility of spillover effects across stock markets in different countries. Such an approach has been adopted in Ongena et al. (2003) and Schäfer et al. (2015). We use the Stoxx Global Total Market Net Return Index.

We conduct the study for several sets of companies. The subsamples of companies and their summary statistics are presented in Table 2. Using 92

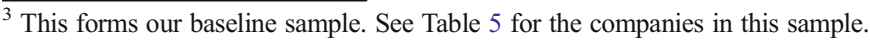


Table 1 Identified events associated with financial market regulation

\begin{tabular}{lll}
\hline Article title & $\begin{array}{l}\text { Publication } \\
\text { date }\end{array}$ & $\begin{array}{l}\text { Event date } \\
\text { Loosening Source } \\
\text { regulation } \\
\text { news }\end{array}$ \\
\hline
\end{tabular}

1A. Events associated with Basel III

Summit

02/04/2009 02/04/2009 no

Bloomberg

Banks win battle for limits to Basel III; Basel III

$25 / 06 / 2010 \quad 25 / 06 / 2010$ yes

FT proposals eased by regulators

Basel deal reached on banks' reserves; Bankers fear 13/09/2010 13/09/2010 no race to toughen regimes

Reducing the moral hazard posed by systemically

$20 / 10 / 2010 \quad 20 / 10 / 2010$ yes

\section{FT} important financial institutions, Wall St dividend constraints are eased

Shadow banks to face global scrutiny, says Turner

$17 / 11 / 2010 \quad 12 / 11 / 2010$ no

FT

Guidance for national authorities operating the

$16 / 12 / 2010 \quad 16 / 12 / 2010$ no

FT, BCBS countercyclical capital buffer, Strengthening the resilience of the banking sector

Basel III break for banks in EU

27/05/2011 27/05/2011 yes

FT

Global Systemically Important Banks: Assessment Methodology and the Additional Loss

19/07/2011 19/07/2011 no

BIS Absorbency Requirement-Rules Text

Basel chief pushes tough line on bank reforms

10/10/2011 10/10/2011 no

Update on Basel III implementation

$18 / 10 / 2011 \quad 18 / 10 / 2011$ no

BIS

Bank regulators reject industry pleas for delay to liquidity buffers

09/01/2012 09/01/2012 no

FT

Progress report on Basel III implementation and procedures for conducting country reviews published by Basel Committee

European Union seeks strict newcurbs to cap

$$
13 / 04 / 2012 \quad 12 / 04 / 2012 \text { no }
$$
bankers' bonuses; EU seeks new curbs to cap bank bonuses

EU to push for binding investor vote on pay

Europe's banks face tougher demands

Massive softening' of Basel bank rules

16/05/2012 16/05/2012 no

Basel watchdog to close loophole over use of pricey

$25 / 03 / 2013 \quad 22 / 03 / 2013$ no credit protection

$13 / 01 / 2014 \quad 13 / 01 / 2014$ yes

1B. Events associated with AIFMD

Private equity leaders condemn draft EU law

$\begin{array}{llll}20 / 04 / 2009 & 20 / 04 / 2009 & \text { no } & \text { FT } \\ 06 / 05 / 2009 & 06 / 05 / 2009 & \text { no } & \text { FT } \\ 10 / 08 / 2009 & 10 / 08 / 2009 & \text { yes } & \text { FT } \\ 23 / 10 / 2009 & 23 / 10 / 2009 & \text { yes } & \text { FT } \\ & & & \\ 10 / 02 / 2010 & 10 / 02 / 2010 & \text { yes } & \text { FT } \\ 12 / 03 / 2010 & 12 / 03 / 2010 & \text { yes } & \text { FT } \\ 10 / 05 / 2010 & 10 / 05 / 2010 & \text { no } & \text { FT } \\ 12 / 07 / 2010 & 12 / 07 / 2010 & \text { yes } & \text { FT }\end{array}$

EU 2, Locusts 0

Hope for alternatives redraft

ECB warns Brussels over hedge fund regulation;

ECB sees danger in Europe's hedge fund plan

Veto EU hedge fund curbs, say peers

EU rebuff for Geithner over rules on hedge funds

EU plans hurdles for hedge funds

$12 / 07 / 2010 \quad 12 / 07 / 2010$ yes 
Table 1 (continued)

\begin{tabular}{|c|c|c|c|c|}
\hline Article title & $\begin{array}{l}\text { Publication } \\
\text { date }\end{array}$ & Event date & $\begin{array}{l}\text { Loosening } \\
\text { regulation } \\
\text { news }\end{array}$ & Source \\
\hline Funds and buy-outs braced for rise in regulation & $17 / 11 / 2011$ & $10 / 11 / 2011$ & no & FT \\
\hline Brussels revives funds' fears over rules & $02 / 04 / 2012$ & $02 / 04 / 2012$ & no & FT \\
\hline $\begin{array}{l}\text { BaFin Consultation } 03 / 2013-\text { Scope Of The } \\
\text { KAGB-E/Interpretation Of The Term "Investment } \\
\text { Fund" }\end{array}$ & $03 / 04 / 2013$ & $28 / 03 / 2013$ & no & $\begin{array}{l}\text { Bafin } \\
\text { Consulta- } \\
\text { tion }\end{array}$ \\
\hline German regulator in property U-turn & $01 / 07 / 2013$ & $01 / 07 / 2013$ & yes & FT \\
\hline \multicolumn{5}{|l|}{ 1C. Events associated with EMIR } \\
\hline $\begin{array}{l}\text { Commission proposal for a regulation on OTC } \\
\text { derivatives, central Counterparties and trade } \\
\text { repositories }\end{array}$ & $15 / 09 / 2010$ & $15 / 09 / 2010$ & no & $\mathrm{EC}$ \\
\hline $\begin{array}{l}\text { Geithner urges EU to fall in line with derivatives } \\
\text { rules }\end{array}$ & 09/06/2011 & 09/06/2011 & no & FT \\
\hline Dodd-Frank delays offer OTC reprieve & 06/07/2011 & $15 / 06 / 2011$ & yes & FT \\
\hline Fears on OTC derivatives plan & $15 / 07 / 2011$ & $15 / 07 / 2011$ & no & FT \\
\hline Clearing house push set for delay & $25 / 01 / 2013$ & $25 / 01 / 2013$ & yes & FT \\
\hline Deadline set for derivatives dealers & $08 / 11 / 2013$ & $08 / 11 / 2013$ & no & FT \\
\hline
\end{tabular}

property companies across France, Germany and the U.K., we group the companies into 11 subsamples. Each subsample is based on a selection of approximately the top 15 companies with the highest value in a given category and approximately the top 15 companies with the lowest value in this category. The categories are total assets, debt-to-equity (DE) ratio, and loan-to-value

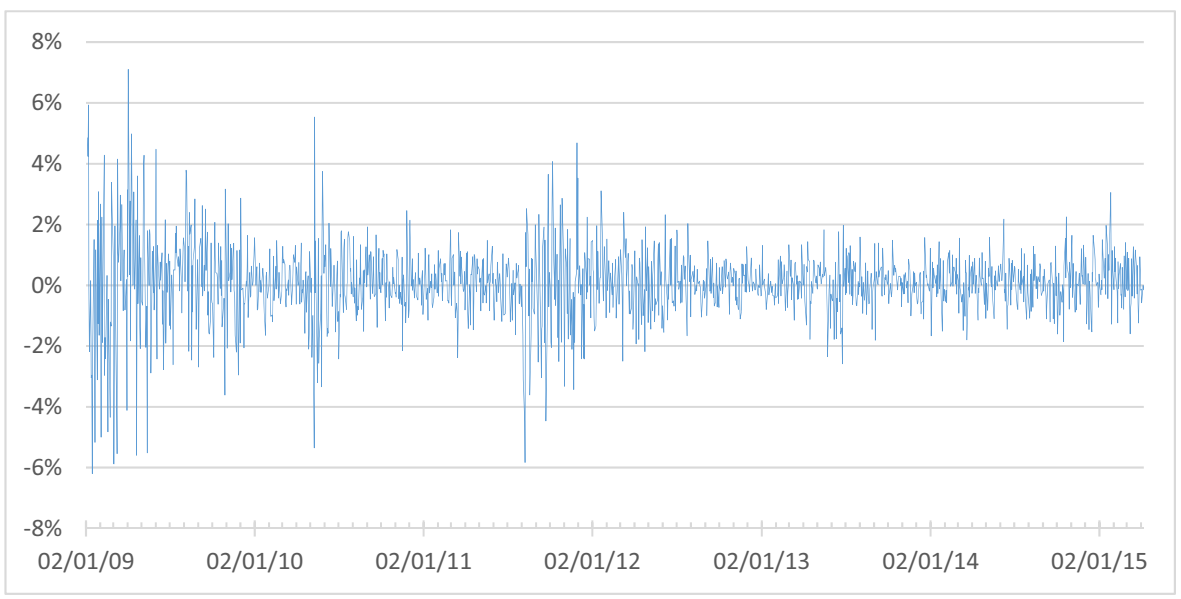

Fig. 4 Weighted average of daily stock returns of the baseline sample of real estate companies. Note: The figure shows equally-weighted returns of the real estate companies in the category largest REITs which are listed in Table 5 
Table 2 Summary statistics of different types of company groupings

\begin{tabular}{lllll}
\hline Types of groupings & Mean & S.D. & Minimum & Maximum \\
\hline Lowest total assets (thousand EUR) & 38,196 & 28,056 & 241 & 89,763 \\
Highest total assets (thousand EUR) & $11,716,398$ & $7,400,860$ & 4813,600 & $35,570,200$ \\
Largest REITs (thousand EUR) & $9,954,926$ & $8,156,053$ & $2,657,391$ & $35,570,200$ \\
Largest non-REITs (thousand EUR) & $5,195,863$ & $3,703,032$ & $1,971,351$ & $14,759,200$ \\
UK largest REITs (thousand EUR) & 4191,121 & $3,926,589$ & 923,900 & $12,171,700$ \\
French largest REITs (thousand EUR) & 7137,124 & $9,287,028$ & 810,400 & $35,570,200$ \\
German largest REOCs (thousand EUR) & $3,486,302$ & $4,251,709$ & 402,196 & $14,759,200$ \\
Lowest DE ratio (\%) & 5 & 7 & 0 & 18 \\
Highest DE ratio (\%) & 336 & 92 & 216 & 541 \\
Lowest LTV (\%) & 18 & 6 & 7 & 26 \\
Highest LTV (\%) & 65 & 13 & 54 & 94 \\
\hline
\end{tabular}

The names of the companies entering in each category are listed in Table 5 in the Appendix. DE stands for debt-to-equity, LTV stands for loan-to-value, REOCs stands for real estate operating companies, REITs stands for real estate investment trusts. In each grouping there are 15 companies with the highest or lowest values in the respective category across France, Germany and the U.K. for 2015

(LTV) ratio. The balance-sheet company data that serves to split the firms into the categories comes from SNL Financial. In addition, we form country-level ${ }^{4}$ subsamples of the REITs with the highest total assets. For Germany, we have a subsample of the 15 German real estate operating companies (REOCs) with the highest total assets. We include REOCs rather than only REITs as most of the active real estate companies in Germany do not have a REIT status and those companies which are REITs do not date back very far, so the time series information is not enough for our estimation. Therefore, we also account for differences between REITs and REOCs by splitting the companies into a large REITs and a large non-REITs sample incusing the companies of all three countries. When selecting the companies, we make sure that we exclude firms which show abnormal return patters and outliers which may be due to changes in the status of the company, a merger, equity issuance, etc. The 92 companies are distributed in 11 subsamples with some of the companies featuring in several subsamples. Almost half (41) of the companies feature in only one subsample. Thirty companies feature in two subsamples and another 20 in three subsamples. Only one company features in four subsamples. Overall, there are 11 samples of 15 companies, so 165 'slots' to fill in the subsamples. With 92 companies split into these 11 samples, this means that typical firm appears in 1.8 samples.

In Table 2, we can see that the companies with the lowest total assets have an average balance sheet size of 38 million euros as opposed to almost 12,000 million euros for the companies in the highest-assets grouping. The smallest

\footnotetext{
${ }^{4}$ This is based on the origin of the company and its headquarters and not on the location of the assets of the company. Some companies may invest internationally as well but as real estate is a highly information intensive asset, managers would prefer to be close to their assets, hence invest in local markets.
} 
company is Black Sea Property Fund Limited from the U.K. with a balance sheet size of 0.241 million euros. The smallest real estate company in the highest-assets category is Segro Plc from the U.K. with a size of 4813 million euros. The largest company in this category is Unibail-Rodamco SE with a size of 35,570 million euros. Within the large-size subsample, we also split the funds into largest REITs and largest non-REITs. Among the 15 largest REITs, there are no German firms and the split is almost equal between U.K. and French companies. Among the largest non-REITs there are mainly German and U.K. firms with the largest company for which data is available being Deutsche Wohnen SE from Germany. The average size among the largest non-REITs is 5196 million euros as compared to 9955 million euros for REITs. When we look at country level data, we see that French companies have the largest size with 7137 million euros on average, followed by U.K. companies with 4191 million euros and German firms with 3586 million euros.

In terms of the DE ratio, the average ratio in the low category is $5 \%$ with the majority of the companies reporting no debt. The average DE ratio in the high category is nearly $800 \%$. A similar proportion of German and U.K. funds are among those which report the highest DE ratios. U.K. funds are however also among those with the lowest DE ratios. The average reported LTV ratio for the low category is $18 \%$ with companies reporting ratios between $7 \%$ and $26 \%$. All of the companies in this category are based in the U.K. The average LTV ratio in the high category is $65 \%$ with a maximum ratio of $94 \%$ for Alpha Pyrenees Trust Limited which also has the highest DE ratio, and a minimum ratio of 54\%. Similar to the DE ratio, most companies are either from the U.K. or Germany. French companies seem not to be in the two extremes for most of the criteria.

\section{Estimation Procedure}

One way to account for the impact of regulatory announcements is to use an event study (Schwert 1981; Binder 1985; Brown and Warner 1985; Lamdin 2001). We measure the effect of a regulatory event on the day of its announcement by calculating the abnormal returns for each company. In order to capture the effect of regulation we augment the market model by event dummy variables (Binder 1985; Schäfer et al. 2015). This approach differs from the standard way event studies are conducted. The majority of research using event studies accounts for abnormal returns by looking at the residuals applying a two-stage OLS regression. The reason for using the dummy variable approach rather than the classical twostage estimation is that our events are associated with regulations simultaneously affecting all companies rather than with company-specific events. Schipper and Thompson (1983) and Campbell et al. (1996) argue that the dummy-variable approach increases the efficiency of the estimation accounting for (1) multiple announcement events for a given regulatory change, (2) high cross-sectional correlation in the residuals, and (3) small sample size. The correlation across the residuals can be due to the fact that the announcement of news occurs on the same date for all companies, as is the case for international regulations and to common industry factors across the companies. The model consists of stock returns regressed on a constant, the return of the market index and event dummy variables for the respective regulation: 


$$
\begin{aligned}
& R_{1 t}=\alpha_{1}+\beta_{1} R_{M t}+\sum_{n=T-1}^{T+1} \tau_{1 n} D_{1 n t}+\varepsilon_{1 t} \\
& \ldots \\
& R_{i t}=\alpha_{i}+\beta_{i} R_{M t}+\sum_{n=T-1}^{T+1} \tau_{i n} D_{i n t}+\varepsilon_{i t} \\
& \ldots \\
& R_{I t}=\alpha_{I}+\beta_{I} R_{M t}+\sum_{n=T-1}^{T+1} \tau_{I n} D_{I n t}+\varepsilon_{I t}
\end{aligned}
$$

with $i$ the return in day $t$ with $i=1, \ldots, I$ and $t=1, \ldots, T+1$, where $T$ is the day of the regulatory announcement. $R_{M t}$ is the global market return which is the same for each company. However, the estimation coefficients - alpha and beta, as well as those for the dummy variables - differ across the companies. $D_{\text {int }}$ denotes a vector of dummy variables for all sub-events in the estimation window associated with one regulation. Normally each equation will contain only one sub-event. However, if during the estimation window there have been previous news associated with the regulation, we follow Schäfer et al. (2015) and include those event dummies as well as a means of 'dummying out' the 'old' news. The idea is that the estimated returns account for previous adjustment to past events and the impact of the news is correctly estimated. For each sub-event there are three dummies. A pre-event dummy that takes the value 1 one day before the event $(T-1)$ and zero otherwise. It is included in order to account for investors anticipating the regulatory news. An event dummy that takes the value 1 on the day of the event $(T)$ and the value of zero otherwise; and a postevent dummy which is equal to 1 one day after the event $(T+1)$ and zero otherwise. The latter is included in order to account for investors who react to regulatory news with some lag due e.g. to differences in trading times. The dummy coefficient $\tau_{\text {in }}$ measures the abnormal return for a company $i$ for a given day $t$ in the event window. The estimation window begins 80 trading days before the sub-event and ends 1 day after it. For robustness purposes, we estimate the models using an estimation window of 40 days and 120 days as well.

We estimate model (1) as a system of equations using a seemingly unrelated regression (SUR) (Zellner 1962; Binder 1985). The alternative would be to use a two-stage least square regression as in Campbell et al. (1996) but the SUR is shown to be more appropriate to estimate the standard errors as it accounts for regulatory events which have a simultaneous effect on a large sample of companies at the same time. For each sub-event a separate system is estimated which leaves us in the case of Basel III with 18 systems for the 18 sub-events.

Moreover, in order to measure the impact of regulatory news on changes of the sensitivity (beta) of each firm to the benchmark, we expand the model in (1) to directly account for regulatory effects on the beta coefficients during the event:

$$
\begin{aligned}
& R_{1 t}=\alpha_{1}+\beta_{1} R_{M t}+\sum_{n=T-1}^{T+1} \tau_{1 n} D_{1 n t}+\delta_{1} D_{1 E t} R_{M t}+\varepsilon_{1 t} \\
& \ldots \\
& R_{i t}=\alpha_{i}+\beta_{i} R_{M t}+\sum_{n=T-1}^{T+1} \tau_{i n} D_{i n t}+\delta_{i} D_{i E t} R_{M t}+\varepsilon_{i t} \\
& \ldots \\
& R_{I t}=\alpha_{I}+\beta_{I} R_{M t}+\sum_{n=T-1}^{T+1} \tau_{I n} D_{I n t}+\delta_{I} D_{I E t} R_{M t}+\varepsilon_{I t}
\end{aligned}
$$


with $D_{i E t}$ an interaction dummy variable which is set equal to one during the event. The parameter $\delta_{i}$ accounts for the instantaneous change in the asset's sensitivity to the market which occurs on the day of the announcement. As discussed by Lamdin (2001), $\delta_{i}$ is an estimate of the transitional response of beta as it captures the change in beta only during the event but not before or after the regulatory announcement. Therefore, model (2) simultaneously tests for the required return effect $\left(\beta_{i}\right)$ and the revaluation effect $\left(\delta_{i}\right)$.

\section{Timeline for Basel III News}

Figure 5 shows the relationship between the market return and the return of the companies from the baseline sample which includes the large REITs from the U.K., Germany and France for each of the Basel III news dates. The black line represents the STOXX return. We can see that the market not always responds to news associated with Basel III as for some news it is close to the zero line. In particular for news towards the end of the event window we see little effect on the market as a whole. We also observe that news towards the beginning of the announcement timeline have rather negative impacts whereas news afterwards have more scattered impacts - changing from positive to negative and vice versa. The first news that we identify is on April 2, 2009 and is related to the G20 summit during which the official announcement of Basel III legislation was made. That is followed by a large period of no relevant news and the first new announcement is associated with another G20 meeting on June 26-27, 2010 which is announcing some relaxation on the initial stance regarding the banking regulation. News thereafter appear quite frequently (one every 1 or 2 months) and some of them are related to press releases by institutions such as the Financial Stability

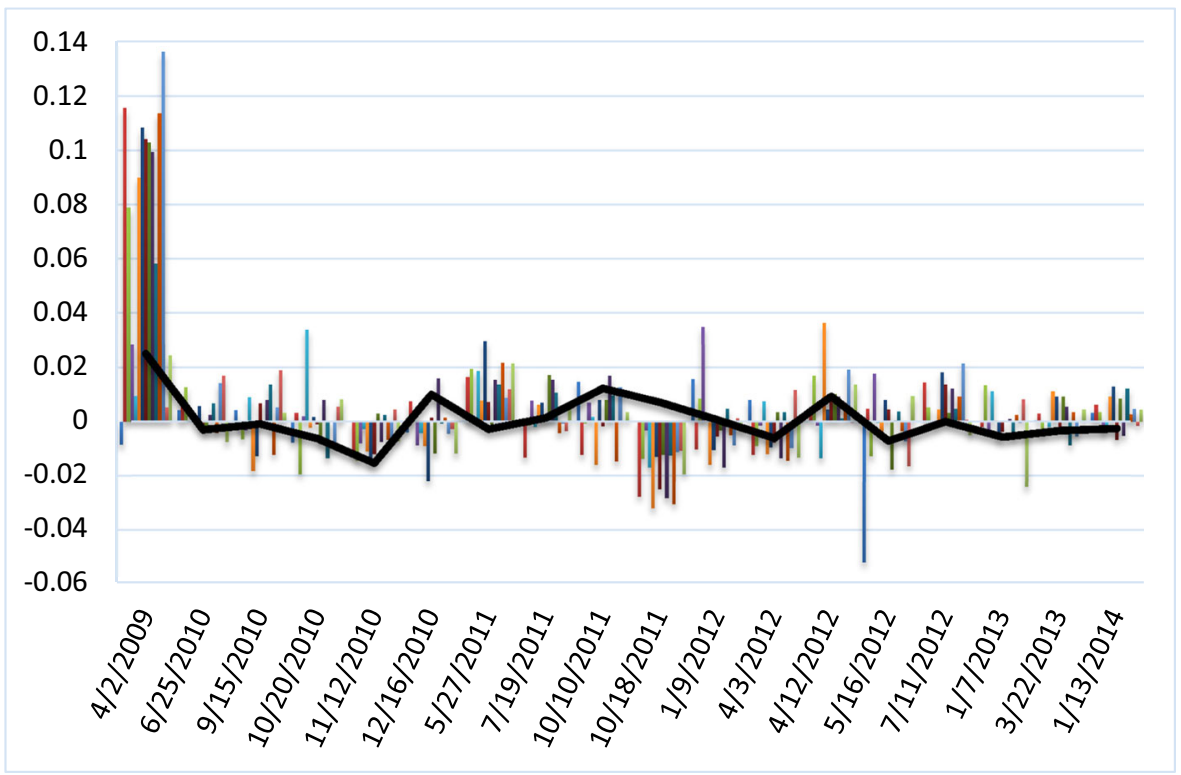

Fig. 5 Timeline of Basel III news and stock market returns. Note: The figure shows the daily returns in the category largest REITs which are listed in Table 5 (bars) along with the market return based on the STOXX European Index (line) 
Board (FSB), the Bank of International Settlements (BIS) or the European Banking Authority (EBA). Some of the news are not associated with official regulatory documents but rather the expression of opinions of involved parties through interviews. When we collect those dates, we double check in Bloomberg and Google that the article we are using to identify the date of the news is the first one to appear and there are no other releases in other media prior to that. This is done on a case-by-case basis since the small number of events allows us to do so.

REIT returns respond to the news along the timeline differently. Some news (the first announcement on February 2, 2009, May 27, 2011, October 18, 2010) have strong uniform effects across all REITs, other announcements have opposite effects with some returns increasing, others falling (September 15, 2009, October 10, 2011, April 3, 2012, May 16, 2012). The strongest overall price changes have been observed in the very beginning of the Basel III consultations. In the last stages of the event window, the effects diminish. These findings suggest that market participants may get used to more news being announced as the regulation consultations progress and hence may dampen their response. In almost all cases though, the REIT price changes are larger than those of the market index meaning that REITs are proportionally more strongly affected that the average across all types of companies.

\section{Results}

We obtain results for 11 different subsamples - large REITs versus large non-REITs, smallest versus largest REOCs, REOCs with lowest versus highest LTV ratios, REOCs with lowest versus highest DE ratios, REOCs in the U.K., REOCs in France, and REOCs in Germany. The results distinguish across the three regulations - Basel III, AIFMD and EMIR. News about tighter and more restrictive regulation are classified as 'restrictive regulation' news from the point of view of the regulated institution. Announcements which are associated with amendments which relax the regulation for the affected parties are classified as 'loosening regulation' news. Below, we look at the effect of restrictive regulation news and loosening regulation news both together and separately. We would focus on restrictive regulation news as those are the news concerning the affected parties. Moreover, there is a large number of studies showing that markets respond asymmetrically to positive and negative shocks with the response to negative shocks significantly stronger than to positive shocks (Chen et al. 2005; Smales 2015; Williams 2015).

We differentiate between companies responding negatively to news about regulatory tightening (in line with the regulatory burden hypothesis), companies responding positively (in line with the profit-based reaction hypothesis), and companies with no significant response (in line with the irrelevance hypothesis). We summarize the results in Tables 3 and 4. In the Appendix we report detailed results including the average abnormal returns (AARs) for each announcement, each subsample and each regulation along with $p$-values of an F-test for the joint significance of the returns for each announcement.

\section{Basel III}

On average, we observe significant AARs following regulatory news about Basel III in less than $50 \%$ of cases (see Table 3). We use the sample consisting of large REITs for 
Table 3 Percentage of significant AARs to any news about financial market regulation

\begin{tabular}{llll}
\hline & Basel III (out of 18 news events) & AIFMD (out of 12 news events) & EMIR (out of 6 news events) \\
\hline Baseline & $44.44 \%$ & $66.67 \%$ & $33.33 \%$ \\
Beta & $27.78 \%$ & $58.33 \%$ & $33.33 \%$ \\
Small & $50.00 \%$ & $25.00 \%$ & $50.00 \%$ \\
Large & $33.33 \%$ & $58.33 \%$ & $50.00 \%$ \\
Low LTV & $38.89 \%$ & & \\
High LTV & $55.56 \%$ & & \\
Low DE & $50.00 \%$ & & \\
High DE & $44.44 \%$ & & \\
UK & & $33.33 \%$ & \\
France & & $75.00 \%$ & \\
Germany & $33.33 \%$ & \\
\hline
\end{tabular}

The average abnormal return (AAR) is the average return across 15 company returns for each category (subsample). The percentages are calculated as the share of the number of significant responses (AARs) to each type of regulation to the total number of news events for each type of regulation

Table 4 How companies are reacting to tighter regulation news - proportion of significant responses (AARs)

\begin{tabular}{|c|c|c|c|c|}
\hline & & $\begin{array}{l}\text { Significant negative } \\
\text { response to tighter } \\
\text { regulation news }\end{array}$ & $\begin{array}{l}\text { Significant positive } \\
\text { response to tighter } \\
\text { regulation news }\end{array}$ & $\begin{array}{l}\text { Total significant } \\
\text { response to tighter } \\
\text { regulation news }\end{array}$ \\
\hline \multirow{8}{*}{$\begin{array}{c}\text { Basel III (out of } 12 \\
\text { negative news) }\end{array}$} & Baseline & $33.33 \%$ & $25.00 \%$ & $58.33 \%$ \\
\hline & Small & $41.67 \%$ & $16.67 \%$ & $58.33 \%$ \\
\hline & Large & $0.00 \%$ & $41.67 \%$ & $41.67 \%$ \\
\hline & Low LTV & $8.33 \%$ & $33.33 \%$ & $41.67 \%$ \\
\hline & High LTV & $25.00 \%$ & $33.33 \%$ & $58.33 \%$ \\
\hline & Low DE & $50.00 \%$ & $16.67 \%$ & $66.67 \%$ \\
\hline & High DE & $25.00 \%$ & $25.00 \%$ & $50.00 \%$ \\
\hline & Beta baseline & $8.33 \%$ & $16.67 \%$ & $25.00 \%$ \\
\hline \multirow{7}{*}{$\begin{array}{r}\text { AIFMD (out of } 6 \\
\text { negative news) }\end{array}$} & Baseline & $33.33 \%$ & $50.00 \%$ & $83.33 \%$ \\
\hline & UK & $0.00 \%$ & $33.33 \%$ & $33.33 \%$ \\
\hline & France & $33.33 \%$ & $66.67 \%$ & $100.00 \%$ \\
\hline & Germany & $0.00 \%$ & $66.67 \%$ & $66.67 \%$ \\
\hline & Small & $16.67 \%$ & $16.67 \%$ & $33.33 \%$ \\
\hline & Large & $16.67 \%$ & $66.67 \%$ & $83.33 \%$ \\
\hline & Beta baseline & $16.67 \%$ & $50.00 \%$ & $66.67 \%$ \\
\hline \multirow{4}{*}{$\begin{array}{l}\text { EMIR (out of } 4 \\
\text { negative news) }\end{array}$} & Baseline & $0.00 \%$ & $50.00 \%$ & $50.00 \%$ \\
\hline & Beta baseline & $0.00 \%$ & $25.00 \%$ & $25.00 \%$ \\
\hline & Small & $25.00 \%$ & $0.00 \%$ & $25.00 \%$ \\
\hline & Large & $50.00 \%$ & $0.00 \%$ & $50.00 \%$ \\
\hline
\end{tabular}

The percentages are calculated as the proportion between the number of significant positive (negative) average abnormal returns (AARs) for each subsample and the total number of tighter regulation news events for each type of regulation 
the baseline estimation. In eight out of the 18 Basel III news, we observe significant AARs which vary between as low as $-5.3 \%$ and as high as $1.6 \%$ (see Table 6 ). These figures show a stronger shift to the left side of the distribution as compared with Schäfer et al. (2015) who report AARs between $-2.2 \%$ and $2.7 \%$ following Dodd-Frank Act announcements. This suggests that REITs seem to be strongly negatively affected by banking regulation news suggesting that markets can fear the negative effects from the bank lending channel. This means that any news about Basel III in that early stage in 2010-2012 spread fears among REIT investors about potential borrowing constraints from banks.

Comparing the results across the different subsamples, we find that there are only small differences across them. The most significant AARs are observed for companies with high LTV ratios (Table 7). In 55\% of the news events regarding Basel III, AARs of companies with high LTVs are significant. Small companies and companies with low DE ratios also show significant responses in $50 \%$ of the cases. Those results however are based on all news and hence it is hard to say anything about the underlying drivers of the significance. Therefore, in what comes next, we examine in more detail how tighter regulation news, in particular, affect the subsamples and analyze the extent of the asymmetric reaction.

Overall, we observe asymmetric effects to news with tighter regulation news causing a stronger return reaction than loosening regulation news. This is in line with previous studies (Williams 2015) which show that the response to negative shocks is stronger than to positive shocks. Companies with low DE ratios and small companies are among those most negatively affected by the regulatory news (see Table 4). This is in line with the regulatory burden hypothesis (see Figs. 1 and 2) postulating that financial market regulation may increase the costs for financial institutions and pass them through to borrowers. Even though Basel III does not regulate real estate companies directly, the banking regulation can affect property company returns through the bank lending channel as described above. Basel III tightens the capital requirements for specific types of real estate loans such as some development loans and project loans. As a result, banks may decide to reduce their credit provision or increase the credit costs for those borrowers. Therefore, companies which more heavily rely on bank borrowing would be more strongly affected by Basel III announcements as shown in our results.

Table 4 shows that the most indebted companies in terms of LTV ratios respond more frequently to tightening Basel III news than companies which have among the lowest LTV ratios. However, the economic significance is small, as only in $25 \%$ of the events we see a significant decrease in the AARs. This is less than the $33 \%$ for which we observe significant positive AARs. Therefore, we do not find strong evidence that more indebted companies per se respond more strongly to negative Basel III news. This is also the case when we sort by DE ratio. We observe that companies with high DE ratios respond significantly only in $25 \%$ of the events. In another $25 \%$ of cases the effect is significantly positive. This supports the irrelevance hypothesis associated with regulatory arbitrage. Companies with a high proportion of debt relative to their equity may have diversified their funding sources and do not heavily rely on bank borrowing. That would enable them to tap into other sources of funding from less regulated financial institutions or issue their own debt. This is supported by the fact that companies with low DE ratios respond to tightening Basel III news negatively in $50 \%$ of the events as opposed to only $17 \%$ for which the response is positive. This 
highlights that companies with low DE ratios may more heavily rely on bank funding even though their debt proportion is low. Small companies with limited access to alternative financing are the ones most negatively affected by tightening in banking regulation as they report the highest share of significant negative AARs. So, for small firms we find evidence for the regulatory burden hypothesis in line with previous studies (Dean and Brown 1995; Beck et al. 2005; Rice and Strahan 2010). That shows that tight regulations have the most negative impact on small companies as such firms may not be able to cover the increase in compliance and other costs associated with the reforms. This may lead to consolidation on the market for real estate companies. Our results are similar to Beck et al. (2005) who find that the smallest firms are most adversely affected by regulatory barriers. Schäfer et al. (2015) also conclude that regulatory announcements have different effects on small versus large banks. They find that large systemically important banks show higher responses to regulatory announcements as they are subject to tighter regulations than small banks.

In terms of changes in the beta coefficient, we can see that Basel III does not lead to changes in the systematic risk of the companies as measured by the abnormal beta on the day of the event (see Table 10). It seems that the overall exposure to the market is not affected following that regulation.

\section{AIFMD}

Real estate firms respond more frequently to news about AIFMD than about Basel III. In the baseline case, in $67 \%$ of the news events regarding AIFMD we find a significant response (see Table 3). The strong effects of AIFMD news can be due to the fact that this regulation targets non-UCITS funds which have previously been much less regulated and hence the news would not have been anticipated. The AAR varies between $-5.5 \%$ and $1 \%$ (see Table 6). We have an equal split between tightening and loosening news with the former having by far a stronger effect on returns than the latter. Similar as above, this provides evidence for asymmetric responses to news. This is in line with previous research showing asymmetrical responses to shocks on the housing and stock markets (Copper et al. 2000; McDonald et al. 2000; Tsai et al. 2012; Hoesli and Reka 2013). However, we find that market participants are not always responding negatively to tighter regulation news. In $50 \%$ of the events, in fact, they are responding positively to regulatory tightening as opposed to $33 \%$ of a positive responses. This is in line with the profit-based reaction hypothesis that regulation is not perceived as a burden but rather seen as a means to increased efficiency and lower systemic risks. The initial draft of the AIFMD does not specify whether REITs fall within the regulation but if they are regarded as alternative funds, then they would be regulated. At a later stage, the confusion has been resolved with most of the REITs falling outside of the regulation. However, at the time of the news announcements this was not known and hence we observe significant abnormal returns. As it was not clear if AIFMD would affect real estate companies, real estate firms may have seen it as an arbitrage opportunity in which if they were not regulated while other similar entities are, the regulation would prove arbitrage opportunities.

We find that the positive regulatory effect is particularly strong for large real estate firms with $67 \%$ of the AARs responding significantly positive. This can mean that large 
firms can extract most value from the regulatory arbitrage opportunity due to economies of scale. Small companies seem not to be strongly affected by the news.

We also look at how regulation has impacted companies from different European countries looking at large real estate firms from France, Germany and the U.K. (see Table 9). The reason is that it is down to the country to decide the way in which companies should comply with the AIFMD. We find that French companies are by far most affected by AIFMD with significant responses to negative news in each news event. German real estate companies respond in $67 \%$ of the cases. However, we observe that the effects on AARs are positive in most of those cases. This can be related to size issues as described above (French companies are the largest in our sample). We do not find strong effects of AIFMD in the U.K. This may be due to the structure of the British real estate firms which are rather structured as operating companies rather than as funds.

In terms of the systematic risk of real estate firms, we can see that the AIFMD regulation leads to significant changes in the beta coefficient on the day of the announcement (see Table 10) in 58\% of the cases. In most of the cases, the effect on the performance is negative, with beta increasing significantly. When there is negative news related to AIFMD, i.e. announcing tighter regulation, we observe an increase in the beta coefficient. Beta increases by 0.001 on average following the news. This means that real estate companies would be more exposed to market variations following the regulatory announcements which can be due to the uncertainty surrounding the regulation, i.e. how real estate companies are treated and if they fall within the regulation. Sing et al. (2016) show that the high beta of some REITs can be explained by a leverage factor suggesting that more indebted REITs would have a high beta.

\section{EMIR}

EMIR is a much smaller regulation as compared to Basel III. However, it can affect all financial institutions which trade derivatives. For this reason, we also assess the impact of it and compare it to the effects of large-scale regulations. The baseline results in Table 3 show that EMIR has overall small impact on real estate company returns. The AAR varies between $-1 \%$ and $0.4 \%$ across the news (see Table 6). This effect is much smaller than the effects observed for the above two regulations which is understandable given the small scope of this regulation.

Furthermore, we do not find that there are large differences between large and small companies (see Table 3). However, looking only at the tighter regulatory news associated with EMIR, we can see that large companies are more strongly negatively affected than small ones (see Table 8). This makes sense since most of the large companies actively hedge interest rate and exchange rate risks using derivatives such as swaps. Hence we can interpret this finding as showing evidence for prevailing negative effects of EMIR for large companies due to the collateral costs of hedging.

\section{Robustness Tests}

Table 11 shows results for estimations using an alternative market index - the MSCI global - and alternative estimation windows - 40 days and 120 days. Overall, the results are robust when using the alternative market index across the different specifications. With regards to the estimation windows, we observe that there are more significant 
announcements for the 40-day rolling window than for the 80-day window. When the sample is estimated using 120 days, there are even fewer significant responses. We also perform a placebo test in which we use random dates of events for each of the regulations and find out that there are fewer significant responses which highlights that our event identification strategy has been successful at recognizing news.

\section{Concluding Remarks}

This study assesses the impacts of announcements about international financial market regulatory reforms following the GFC on the equity performance of listed real estate companies. We look at the impacts of three international regulations undertaken in the aftermath of the GFC - Basel III, AIFMD and EMIR - on the returns of European real estate companies. The regulations have different scopes and regulate distinct financial institutions. While Basel III is a large-scale banking regulation widely discussed in the media, EMIR has much smaller media coverage. However, Basel III regulates only banks while EMIR can affect all financial institutions which trade derivative products.

The challenge to assess the impact of the regulations lies in identifying the event dates associated with regulatory announcements. The reason is that large-scale reforms are phased out over many years and their final enactment may already have been anticipated by market participants. Therefore, we employ an event study methodology using daily financial market data. The regulatory event dates are manually identified using articles in international financial newspapers and news agencies. As we look at regulatory reforms enacted at the European level, we compare the effects across several European countries (the U.K., Germany, and France) with the largest listed real estate sectors.

Our results show large differences across the three regulations. Basel III and EMIR have overall small aggregate effects on the performance as they do not directly regulate real estate companies. However we find some support for the regulatory burden hypothesis of the bank lending channel. We document that the banking regulation negatively affects small firms and firms with low debt-toequity ratios. This may suggest that the strongest effect is observed for firms who cannot diversify their funding sources and are thus hit strongest by Basel III. The direct regulatory channel through the AIFMD supports rather the profit-based reaction hypothesis. Mainly large firms are affected positively by the regulation which can be due to identified regulatory arbitrage opportunities for real estate companies if they do not have to comply with AIFMD. Overall, we see that different regulation can have opposite effects on companies and it is important to look at them separately as well as assess the impacts of tighter regulation and loosening regulation news separately. We find strong evidence for asymmetric effects with tighter regulation news more frequently leading to significant responses.

Acknowledgements We thank the European Public Real Estate Association (EPRA) for financial support. We also thank Andy Naranjo, our discussant at the University of Cambridge-University of Florida-National University of Singapore symposium, and the anonymous reviewers for very helpful suggestions. 
M. Hoesli et al.

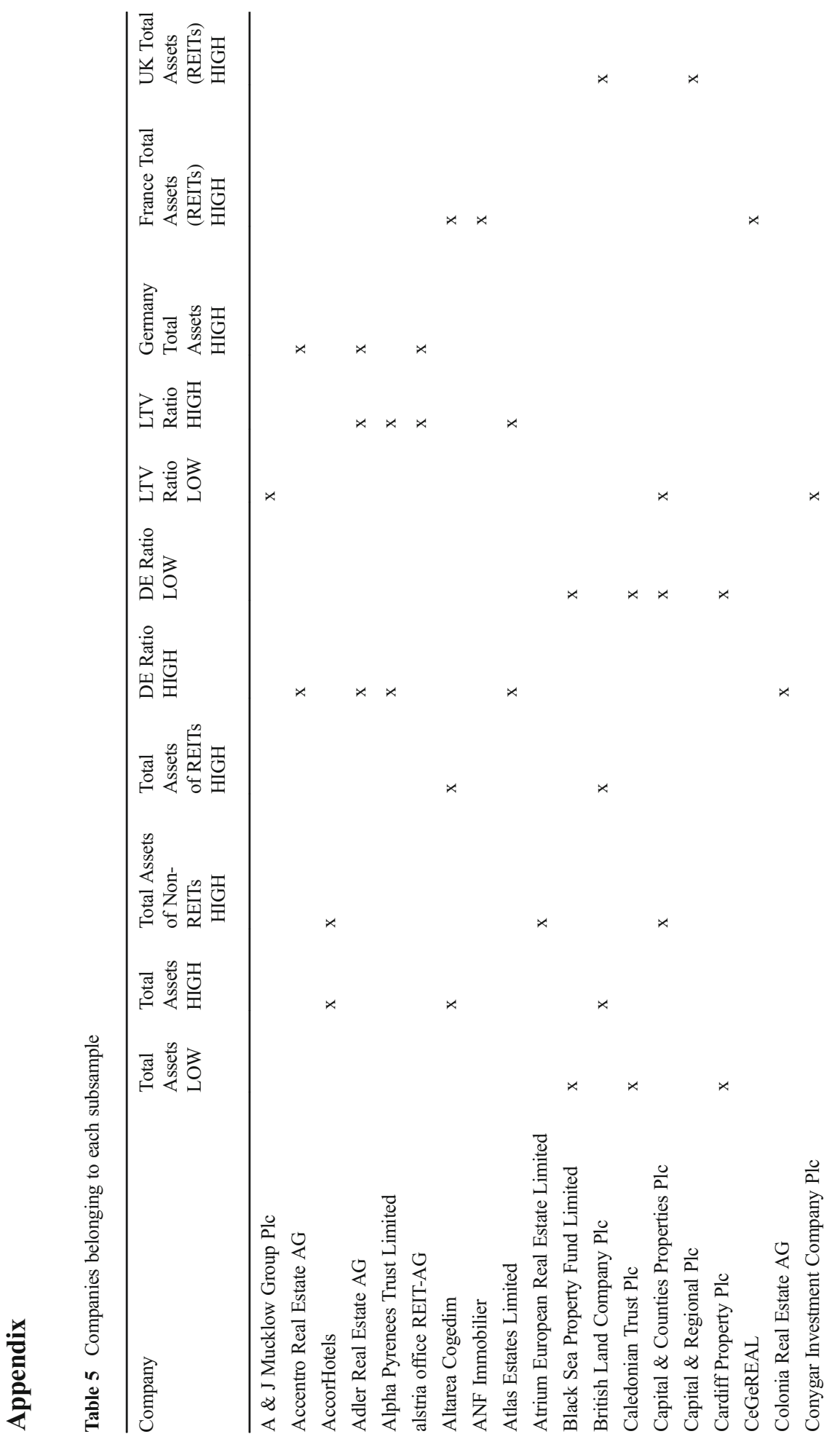




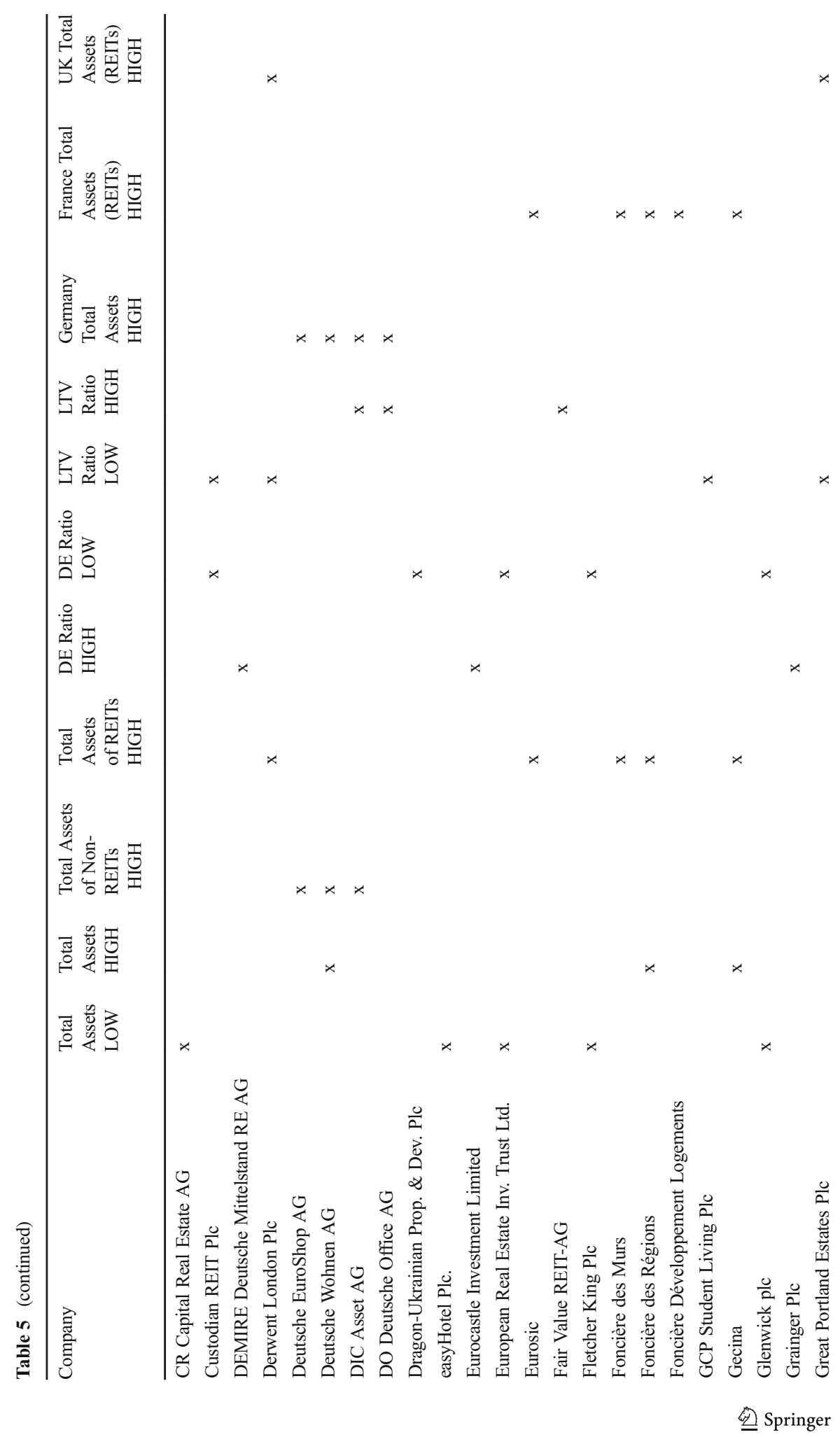




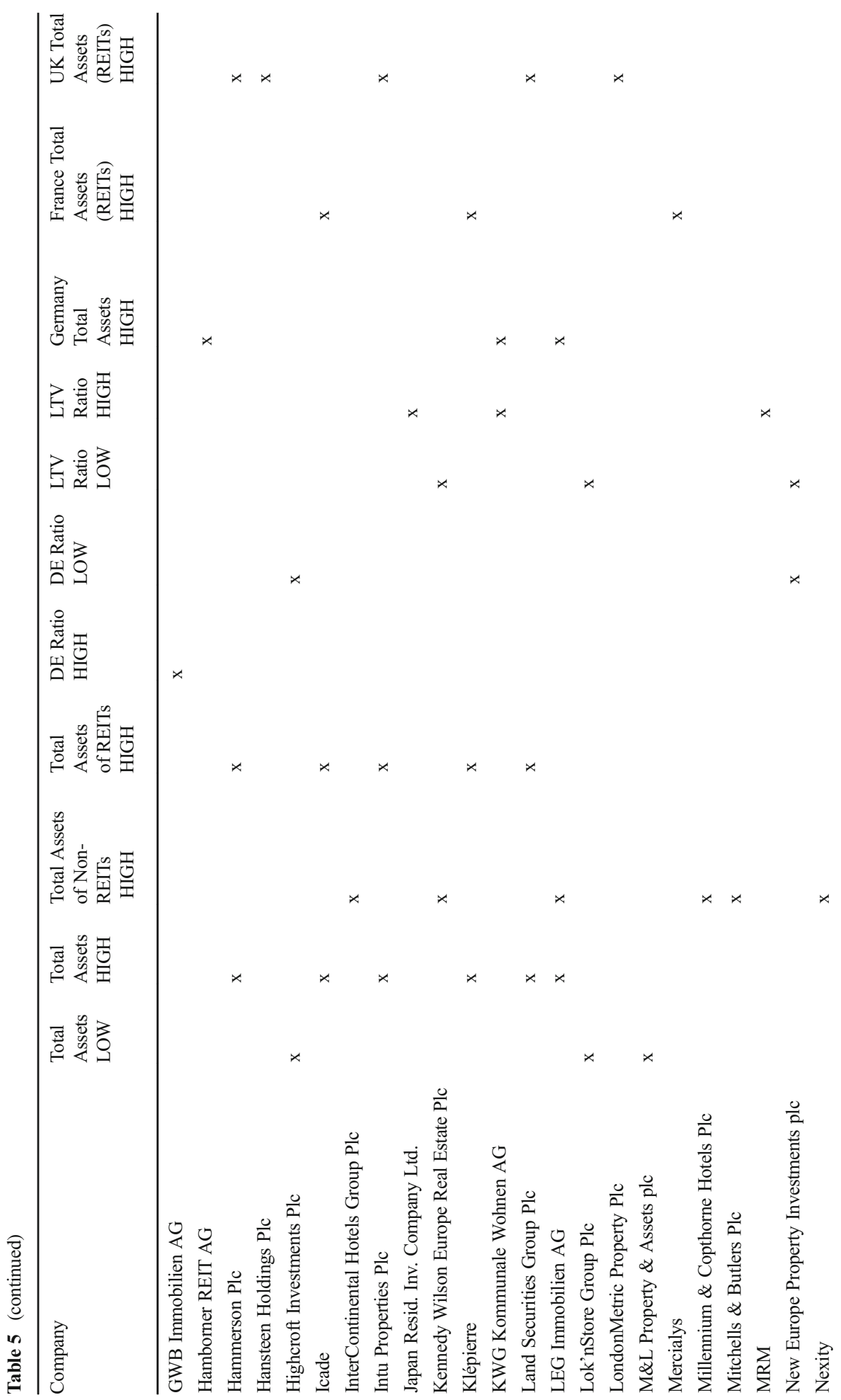




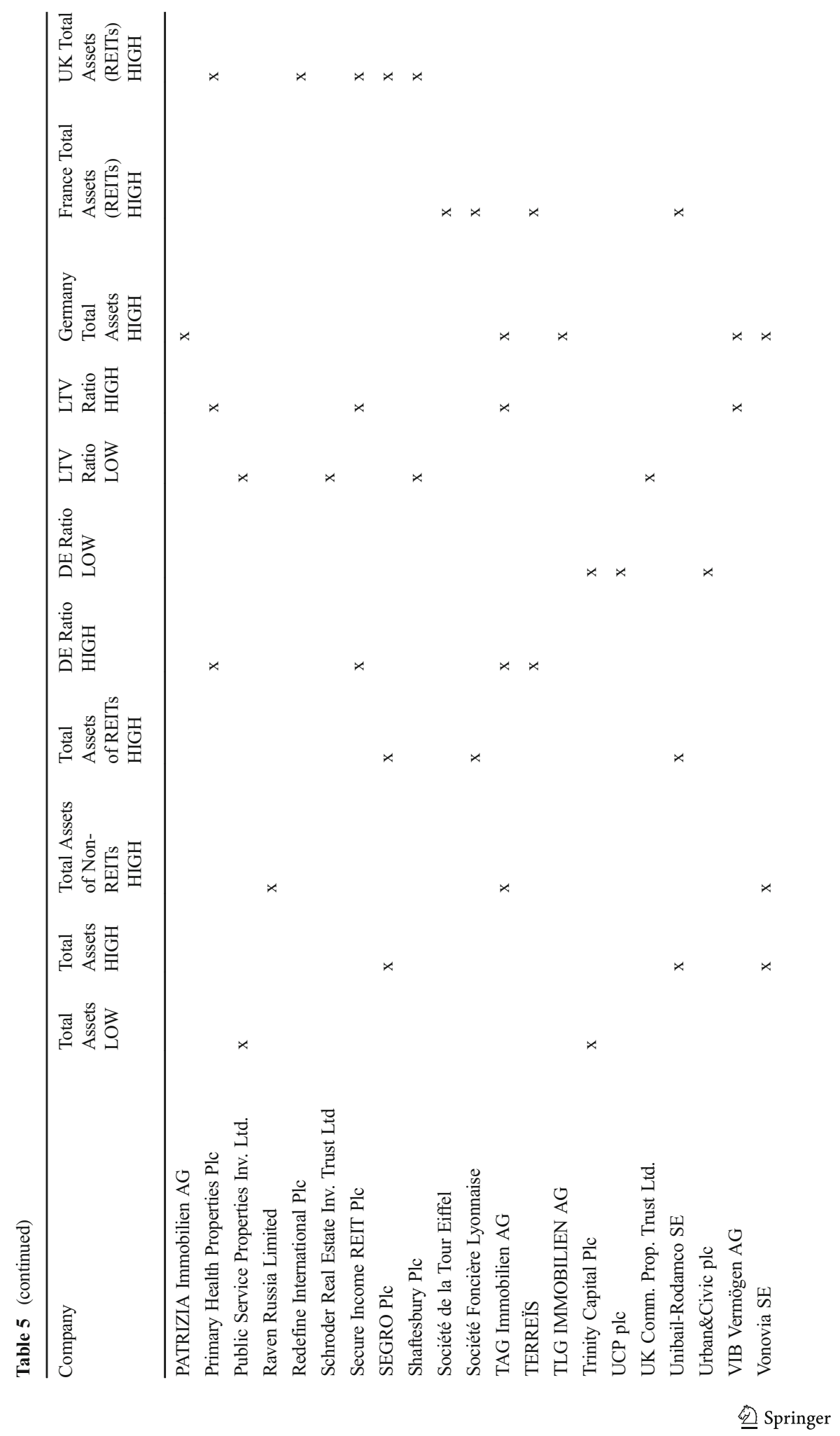




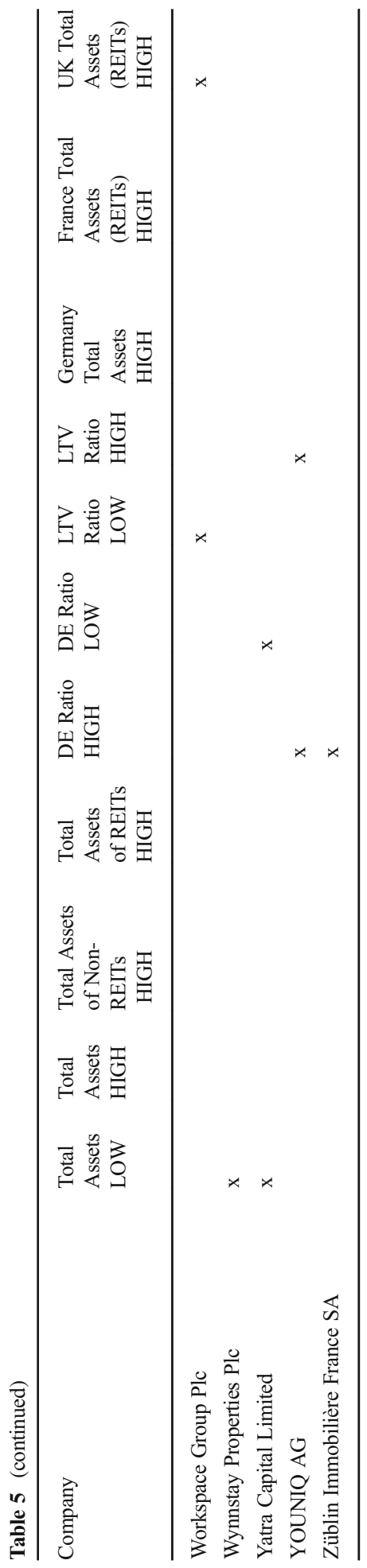

包 Springer 
Table 6 Average abnormal returns for large European real estate companies associated with news about Basel III, AIFMD and EMIR

\begin{tabular}{|c|c|c|c|c|c|}
\hline \multicolumn{6}{|l|}{ A. Basel III } \\
\hline \multirow[t]{2}{*}{ Event Date } & \multirow[t]{2}{*}{ Positive news } & \multicolumn{2}{|c|}{ Large non-REITs } & \multicolumn{2}{|l|}{ Large REITs } \\
\hline & & AAR & $p$-value & AAR & $p$-value \\
\hline 02/04/2009 & no & $0.0321 *$ & 0.0934 & $-0.0057 * * *$ & 0.0001 \\
\hline $25 / 06 / 2010$ & yes & -0.0130 & 0.2149 & 0.0033 & 0.8975 \\
\hline $13 / 09 / 2010$ & no & 0.0183 & 0.8051 & $0.0128 *$ & 0.0843 \\
\hline $20 / 10 / 2010$ & yes & 0.0046 *** & 0.0002 & -0.0055 & 0.1017 \\
\hline $12 / 11 / 2010$ & no & 0.0368 & 0.7347 & -0.0005 & 0.8110 \\
\hline $16 / 12 / 2010$ & no & -0.0023 & 0.6576 & -0.0069 & 0.2467 \\
\hline $27 / 05 / 2011$ & yes & 0.0216 & 0.9910 & -0.0001 & 0.4271 \\
\hline 19/07/2011 & no & $0.0340 * * *$ & 0.0001 & $0.0008 * * *$ & 0.0001 \\
\hline $10 / 10 / 2011$ & no & -0.0018 & 0.7653 & 0.0105 & 0.6662 \\
\hline 18/10/2011 & no & -0.0147 & 0.8281 & $-0.0018 * *$ & 0.0282 \\
\hline 09/01/2012 & no & $-0.0130 * * *$ & 0.0046 & $0.0161 * * *$ & 0.0000 \\
\hline 03/04/2012 & yes & 0.0031 & 0.6065 & 0.0078 & 0.5381 \\
\hline $12 / 04 / 2012$ & no & 0.0172 & 0.9869 & 0.0013 & 0.2474 \\
\hline $16 / 05 / 2012$ & no & $0.0146 * * *$ & 0.0000 & $-0.0528 * * *$ & 0.0000 \\
\hline $11 / 07 / 2012$ & no & -0.0110 & 0.9993 & 0.0022 & 0.6311 \\
\hline 07/01/2013 & yes & $0.0035 * * *$ & 0.0030 & $-0.0004 * * *$ & 0.0046 \\
\hline $22 / 03 / 2013$ & no & $0.0022 * * *$ & 0.0089 & $-0.0029 * * *$ & 0.0000 \\
\hline $13 / 01 / 2014$ & yes & $0.0086 *$ & 0.0656 & 0.0022 & 0.4255 \\
\hline \multicolumn{6}{|l|}{ B. AIFMD } \\
\hline \multirow[t]{2}{*}{ Event date } & \multirow[t]{2}{*}{ Positive news } & \multicolumn{2}{|c|}{ Large non-REITs } & \multicolumn{2}{|l|}{ Large REITs } \\
\hline & & AAR & $p$-value & AAR & $p$-value \\
\hline $20 / 04 / 2009$ & no & -0.0230 & 0.1891 & $0.0064 * *$ & 0.0253 \\
\hline 06/05/2009 & no & $0.0083 * * *$ & 0.0000 & $0.0112 * * *$ & 0.0022 \\
\hline 10/08/2009 & yes & 0.0159 & 0.3303 & $0.0014 * *$ & 0.0159 \\
\hline $23 / 10 / 2009$ & yes & -0.0153 & 0.4447 & 0.0004 & 0.9913 \\
\hline $10 / 02 / 2010$ & yes & 0.0083 & 0.9447 & $-0.0004 * * *$ & 0.0000 \\
\hline $12 / 03 / 2010$ & yes & 0.0063 & 0.9980 & 0.0004 & 1.0000 \\
\hline $10 / 05 / 2010$ & no & $0.0451 * * *$ & 0.0000 & $0.0079 * * *$ & 0.0000 \\
\hline $12 / 07 / 2010$ & yes & -0.0045 & 0.6732 & -0.0105 & 0.8312 \\
\hline $10 / 11 / 2011$ & no & 0.0029 & 0.6747 & $-0.0551 * *$ & 0.0107 \\
\hline 02/04/2012 & no & -0.0020 & 0.9137 & 0.0043 & 0.9831 \\
\hline $28 / 03 / 2013$ & no & 0.0080 & 0.4320 & $-0.0029 * * *$ & 0.0000 \\
\hline $01 / 07 / 2013$ & yes & 0.0200 & 0.2771 & $-0.0094 *$ & 0.0520 \\
\hline
\end{tabular}


Table 6 (continued)

\begin{tabular}{llllll}
\hline C. EMIR & & & & & \\
Event date & Positive news & Large non-REITs & & Large REITs & $p$-value \\
& & AAR & $p$-value & AAR & 0.0023 \\
$15 / 09 / 2010$ & no & -0.0060 & 0.4217 & $0.0042 * * *$ & 0.9992 \\
$09 / 06 / 2011$ & no & 0.0064 & 0.9317 & -0.0003 & 0.9996 \\
$15 / 06 / 2011$ & yes & -0.0204 & 0.9472 & -0.0012 & 0.0240 \\
$15 / 07 / 2011$ & no & $-0.0196 * * *$ & 0.0020 & $0.0019 * *$ & 0.0694 \\
$25 / 01 / 2013$ & yes & $0.0137 *$ & 0.0653 & $-0.0012 *$ & 0.2291 \\
$08 / 11 / 2013$ & no & -0.0023 & 0.2598 & -0.0103 & \\
\hline
\end{tabular}

The table shows the average abnormal return (AAR) for the baseline sample. The results are based on SUR regressions using an estimation window of 80 trading days. AARs are estimated on the basis of the Stoxx Total Market Return Index. The dependent variable is daily stock returns of real estate companies. All regressions include pre-event and post-event dummies in order to account for anticipation effects. Moreover, other news associated with the regulation in case they fall within the estimation window are dummied out 


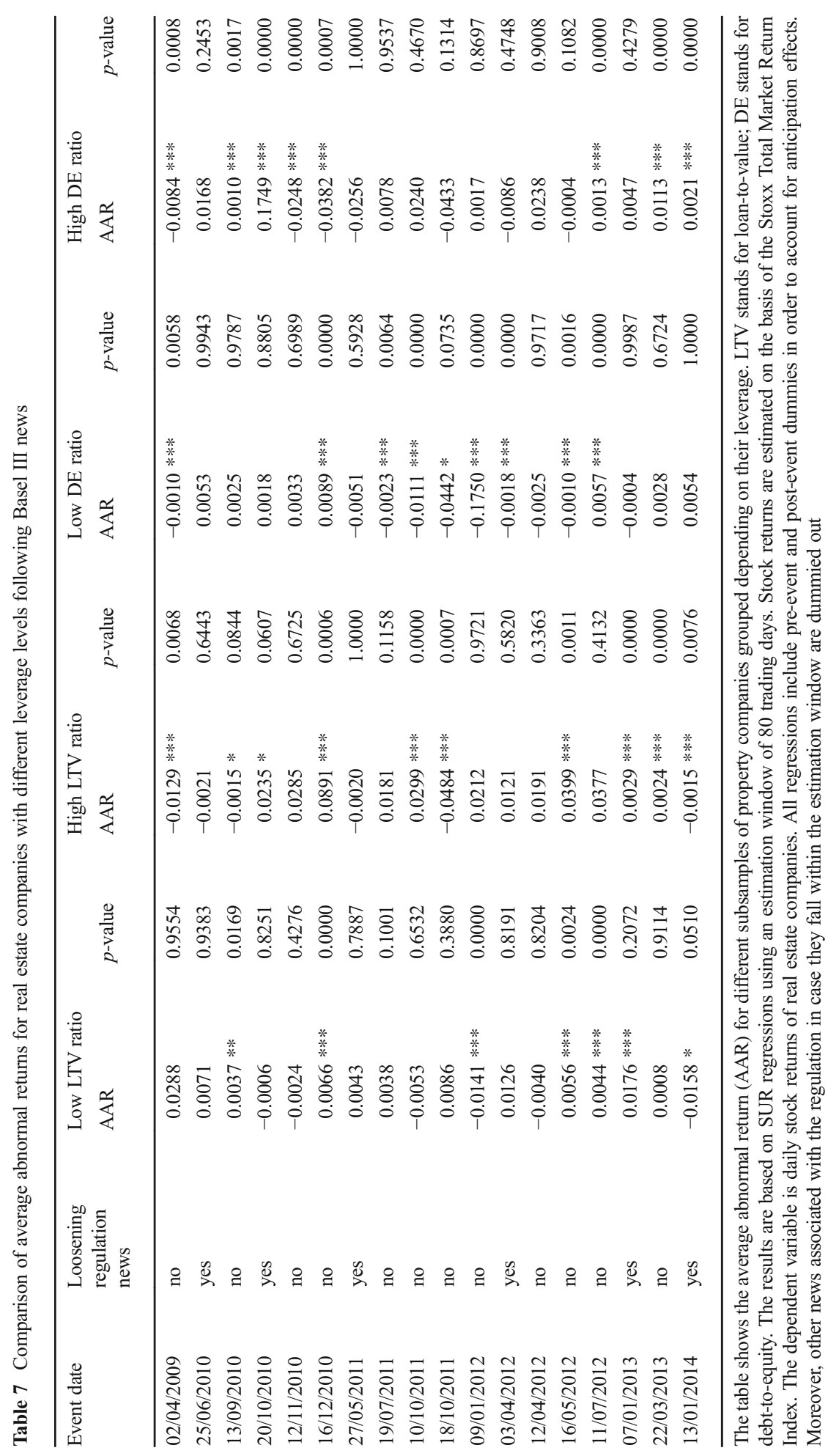


Table 8 Comparison of average abnormal returns for small versus large real estate operating companies (REOCs)

\begin{tabular}{|c|c|c|c|c|c|}
\hline \multirow[t]{2}{*}{ Event date } & \multirow[t]{2}{*}{ Positive news } & \multicolumn{2}{|l|}{ Small REOCs } & \multicolumn{2}{|l|}{ Large REOCs } \\
\hline & & AAR & $p$-value & AAR & $p$-value \\
\hline \multicolumn{6}{|l|}{ A. Basel III } \\
\hline 02/04/2009 & no & $-0.0010 * * *$ & 0.0000 & $0.0321 * * *$ & 0.0000 \\
\hline $25 / 06 / 2010$ & yes & 0.0053 & 0.9979 & -0.0130 & 0.8204 \\
\hline $13 / 09 / 2010$ & no & 0.0025 & 0.4315 & 0.0183 & 0.3131 \\
\hline $20 / 10 / 2010$ & yes & 0.0018 & 0.9897 & $0.0046 * * *$ & 0.0012 \\
\hline $12 / 11 / 2010$ & no & 0.0033 & 0.5618 & 0.0368 & 0.3671 \\
\hline $16 / 12 / 2010$ & no & $0.0089 * * *$ & 0.0000 & -0.0023 & 0.3620 \\
\hline $27 / 05 / 2011$ & yes & -0.0051 & 0.6526 & 0.0216 & 0.4209 \\
\hline 19/07/2011 & no & $-0.0023 * * *$ & 0.0010 & $0.0340 * * *$ & 0.0030 \\
\hline $10 / 10 / 2011$ & no & $-0.0111 * * *$ & 0.0046 & -0.0018 & 0.3254 \\
\hline $18 / 10 / 2011$ & no & -0.0442 & 0.2141 & -0.0147 & 0.1918 \\
\hline 09/01/2012 & no & $-0.1750 * * *$ & 0.0000 & -0.0130 & 0.2711 \\
\hline 03/04/2012 & yes & $-0.0018 * * *$ & 0.0000 & 0.0031 & 0.3441 \\
\hline $12 / 04 / 2012$ & no & -0.0025 & 0.9978 & $0.0172 *$ & 0.0574 \\
\hline $16 / 05 / 2012$ & no & $-0.0010 * *$ & 0.0446 & $0.0146 * * *$ & 0.0000 \\
\hline $11 / 07 / 2012$ & no & $0.0057 * * *$ & 0.0000 & -0.0110 & 0.7675 \\
\hline 07/01/2013 & yes & $-0.0004 * * *$ & 0.0000 & 0.0035 & 0.1149 \\
\hline $22 / 03 / 2013$ & no & 0.0028 & 0.9396 & $0.0022 * *$ & 0.0125 \\
\hline $13 / 01 / 2014$ & yes & 0.0054 & 0.9884 & 0.0086 & 0.7145 \\
\hline
\end{tabular}

B. AIFMD

$\begin{array}{ll}20 / 04 / 2009 & \text { no } \\ 06 / 05 / 2009 & \text { no } \\ 10 / 08 / 2009 & \text { yes } \\ 23 / 10 / 2009 & \text { yes } \\ 10 / 02 / 2010 & \text { yes } \\ 12 / 03 / 2010 & \text { yes } \\ 10 / 05 / 2010 & \text { no } \\ 12 / 07 / 2010 & \text { yes } \\ 10 / 11 / 2011 & \text { no } \\ 02 / 04 / 2012 & \text { no } \\ 28 / 03 / 2013 & \text { no } \\ 01 / 07 / 2013 & \text { yes }\end{array}$

$\begin{array}{ll}-0.0108 & 0.8592 \\ -0.0011 & 0.9751 \\ -0.0063 & 0.6069 \\ -0.0156 & 0.9998 \\ 0.0014 & 0.3221 \\ 0.0029 & 1.0000 \\ -0.0018 * * * & 0.0000 \\ -0.0483 & 0.8182 \\ -0.0065 & 0.9999 \\ 0.0041 * * * & 0.0000 \\ 0.0017 & 1.0000 \\ -0.0005 * * * & 0.0004\end{array}$

$\begin{array}{ll}-0.0230 * * * & 0.0014 \\ 0.0083 * & 0.0870 \\ 0.0159 & 0.9742 \\ -0.0153 & 0.9522 \\ 0.0083 * * * & 0.0000 \\ 0.0063 & 0.9998 \\ 0.0451 * * * & 0.0000 \\ -0.0045 & 0.8650 \\ 0.0029 * * & 0.0318 \\ -0.0020 & 0.9214 \\ 0.0080 * * * & 0.0001 \\ 0.0200 * * & 0.0168\end{array}$


Table 8 (continued)

\begin{tabular}{lllllr}
\hline Event date & Positive news & $\begin{array}{l}\text { Small REOCs } \\
\text { AAR }\end{array}$ & $p$-value & AAR & $p$-value \\
\hline C. EMIR & & & & & \\
$15 / 09 / 2010$ & no & 0.0121 & 0.3005 & $-0.0060 * *$ & 0.0474 \\
$09 / 06 / 2011$ & no & 0.0016 & 0.5784 & 0.0064 & 0.9994 \\
$15 / 06 / 2011$ & yes & $0.0065 * *$ & 0.0207 & -0.0204 & 0.9507 \\
$15 / 07 / 2011$ & no & $-0.0042 * * *$ & 0.0000 & $-0.0196 * *$ & 0.0390 \\
$25 / 01 / 2013$ & yes & $-0.0061 * * *$ & 0.0000 & $0.0137 * *$ & 0.0100 \\
$08 / 11 / 2013$ & no & -0.0011 & 0.9990 & -0.0023 & 0.1527 \\
\hline
\end{tabular}

AAR refers to the average abnormal return of the real estate operating companies for each subevent. The results are based on SUR regressions using an estimation window of 80 trading days. Stock returns are estimated on the basis of the Stoxx Total Market Return Index. The dependent variable is daily stock returns of real estate companies. All regressions include pre-event and post-event dummies in order to account for anticipation effects. Moreover, other news associated with the regulation in case they fall within the estimation window are dummied out

Table 9 Comparison of average abnormal returns for U.K., French and German real estate companies following AIFMD news

\begin{tabular}{llllllll}
\hline Event date & Positive news & UK & & \multicolumn{2}{c}{ France } & & Germany \\
& & AAR & $p$-value & AAR & $p$-value & AAR & $p$-value \\
\hline $20 / 04 / 2009$ & no & -0.0642 & 0.8509 & $0.0064 * * *$ & 0.0000 & 0.0161 & 0.3064 \\
$06 / 05 / 2009$ & no & $0.0486 *$ & 0.0946 & $0.0112 * * *$ & 0.0015 & $0.1345 * * *$ & 0.0000 \\
$10 / 08 / 2009$ & yes & 0.0151 & 0.2992 & $0.0014 * * *$ & 0.0000 & 0.1389 & 0.1103 \\
$23 / 10 / 2009$ & yes & -0.0198 & 0.8666 & 0.0004 & 1.0000 & 0.0024 & 0.1309 \\
$10 / 02 / 2010$ & yes & 0.0032 & 0.4250 & $-0.0004 * * *$ & 0.0000 & 0.0501 & 0.9734 \\
$12 / 03 / 2010$ & yes & $0.0151 *$ & 0.0684 & 0.0004 & 1.0000 & 0.0093 & 0.9790 \\
$10 / 05 / 2010$ & no & $0.0427 * * *$ & 0.0000 & $0.0079 * * *$ & 0.0000 & $0.0517 * * *$ & 0.0000 \\
$12 / 07 / 2010$ & yes & 0.0051 & 0.2102 & -0.0105 & 0.8098 & 0.0122 & 0.9882 \\
$10 / 11 / 2011$ & no & -0.0131 & 0.7159 & $-0.0551 * *$ & 0.0098 & $0.0055 *$ & 0.0556 \\
$02 / 04 / 2012$ & no & -0.0007 & 0.5126 & $0.0043 * * *$ & 0.0013 & $0.0038 *$ & 0.0913 \\
$28 / 03 / 2013$ & no & 0.0072 & 0.7385 & $-0.0029 * * *$ & 0.0000 & -0.0030 & 0.6238 \\
$01 / 07 / 2013$ & yes & $0.0097 * * *$ & 0.0002 & $-0.0094 * * *$ & 0.0052 & -0.0163 & 0.5275 \\
\hline
\end{tabular}

The table shows the average abnormal return (AAR) for property companies from the U.K., France and Germany. AAR refers to the average abnormal return of the real estate operating companies in each country for each subevent. The results are based on SUR regressions using an estimation window of 80 trading days. AARs are estimated on the basis of the Stoxx Total Market Return Index. The dependent variable is daily stock returns of real estate companies. All regressions include pre-event and post-event dummies in order to account for anticipation effects. Moreover, other news associated with the regulation in case they fall within the estimation window are dummied out 
Table 10 Changes in beta for large REITs due to regulatory news about Basel III, AIFMD and EMIR

\begin{tabular}{llll}
\hline Event date & $\begin{array}{l}\text { Loosening } \\
\text { regulation news }\end{array}$ & Transitional beta & $p$-value \\
\hline
\end{tabular}

\begin{tabular}{|c|c|c|c|}
\hline \multicolumn{4}{|l|}{ A. Basel III } \\
\hline 02/04/2009 & no & -0.00009 & 0.1813 \\
\hline $25 / 06 / 2010$ & yes & 0.00004 & 0.5708 \\
\hline $13 / 09 / 2010$ & no & 0.00014 & 0.8438 \\
\hline $20 / 10 / 2010$ & yes & -0.00006 & 0.0296 \\
\hline $12 / 11 / 2010$ & no & 0.00000 & 0.5851 \\
\hline $16 / 12 / 2010$ & no & -0.00007 & 0.7456 \\
\hline $27 / 05 / 2011$ & yes & $0.00000 *$ & 0.0990 \\
\hline $19 / 07 / 2011$ & no & $0.00001 *$ & 0.0761 \\
\hline $10 / 10 / 2011$ & no & 0.00012 & 0.3944 \\
\hline $18 / 10 / 2011$ & no & -0.00002 & 0.3322 \\
\hline 09/01/2012 & no & $0.00016 * *$ & 0.0316 \\
\hline 03/04/2012 & yes & 0.00008 & 0.9824 \\
\hline $12 / 04 / 2012$ & no & 0.00001 & 0.5660 \\
\hline $16 / 05 / 2012$ & no & $-0.00053 * * *$ & 0.0000 \\
\hline $11 / 07 / 2012$ & no & 0.00002 & 0.6309 \\
\hline $07 / 01 / 2013$ & yes & $0.00000 * * *$ & 0.0022 \\
\hline $22 / 03 / 2013$ & no & -0.00002 & 0.7156 \\
\hline $13 / 01 / 2014$ & yes & 0.00002 & 0.4717 \\
\hline \multicolumn{4}{|l|}{ B. AIFMD } \\
\hline $20 / 04 / 2009$ & no & $0.00010 * * *$ & 0.0036 \\
\hline 06/05/2009 & no & $0.00016 * *$ & 0.0370 \\
\hline $10 / 08 / 2009$ & yes & $0.00002 * * *$ & 0.0060 \\
\hline $23 / 10 / 2009$ & yes & 0.00000 & 0.9764 \\
\hline $10 / 02 / 2010$ & yes & $0.00000 * * *$ & 0.0002 \\
\hline $12 / 03 / 2010$ & yes & 0.00000 & 0.8942 \\
\hline $10 / 05 / 2010$ & no & $0.00008 * * *$ & 0.0000 \\
\hline $12 / 07 / 2010$ & yes & -0.00012 & 0.6564 \\
\hline $10 / 11 / 2011$ & no & -0.00060 & 0.1133 \\
\hline $02 / 04 / 2012$ & no & 0.00004 & 0.8058 \\
\hline $28 / 03 / 2013$ & no & $-0.00002 * * *$ & 0.0000 \\
\hline $01 / 07 / 2013$ & yes & $-0.00008 *$ & 0.0798 \\
\hline
\end{tabular}


Table 10 (continued)

\begin{tabular}{lllr}
\hline Event date & $\begin{array}{l}\text { Loosening } \\
\text { regulation news }\end{array}$ & Transitional beta & $p$-value \\
\hline C. EMIR & & & 0.1191 \\
$15 / 09 / 2010$ & no & 0.00005 & 0.8990 \\
$09 / 06 / 2011$ & no & 0.00000 & 0.9942 \\
$15 / 06 / 2011$ & yes & -0.00001 & 0.9833 \\
$15 / 07 / 2011$ & no & 0.00002 & 0.0911 \\
$25 / 01 / 2013$ & yes & $-0.00001 *$ & 0.0740 \\
$08 / 11 / 2013$ & no & $-0.00008 *$ & \\
\hline
\end{tabular}

The table shows the average transitional beta value for the day of the news announcement for the baseline sample. The results are based on SUR regressions using an estimation window of 80 trading days. Stock returns are estimated on the basis of the Stoxx Total Market Return Index. The dependent variable is daily stock returns of real estate companies. All regressions include pre-event and post-event dummies in order to account for anticipation effects. Moreover, other news associated with the regulation in case they fall within the estimation window are dummied out 


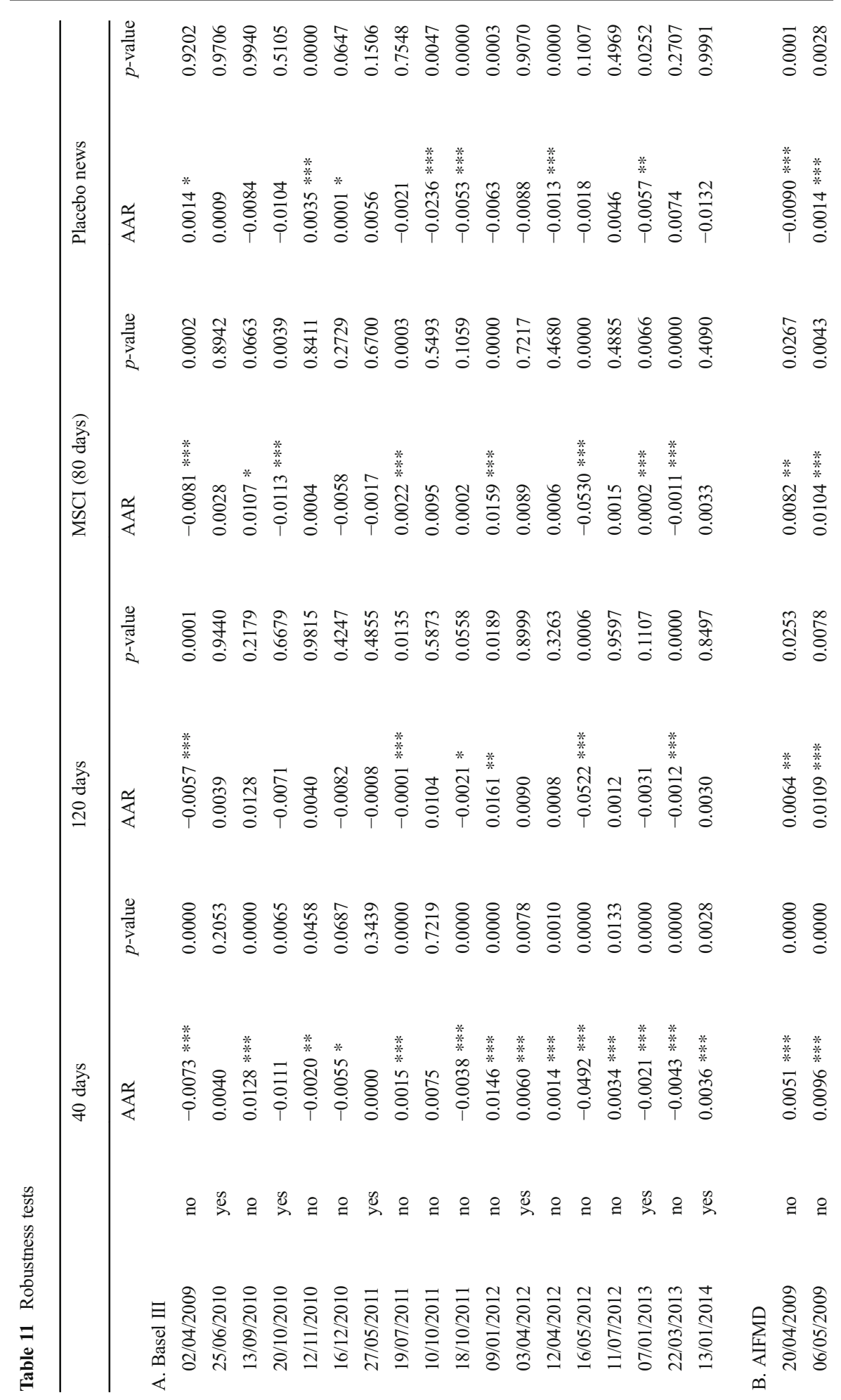




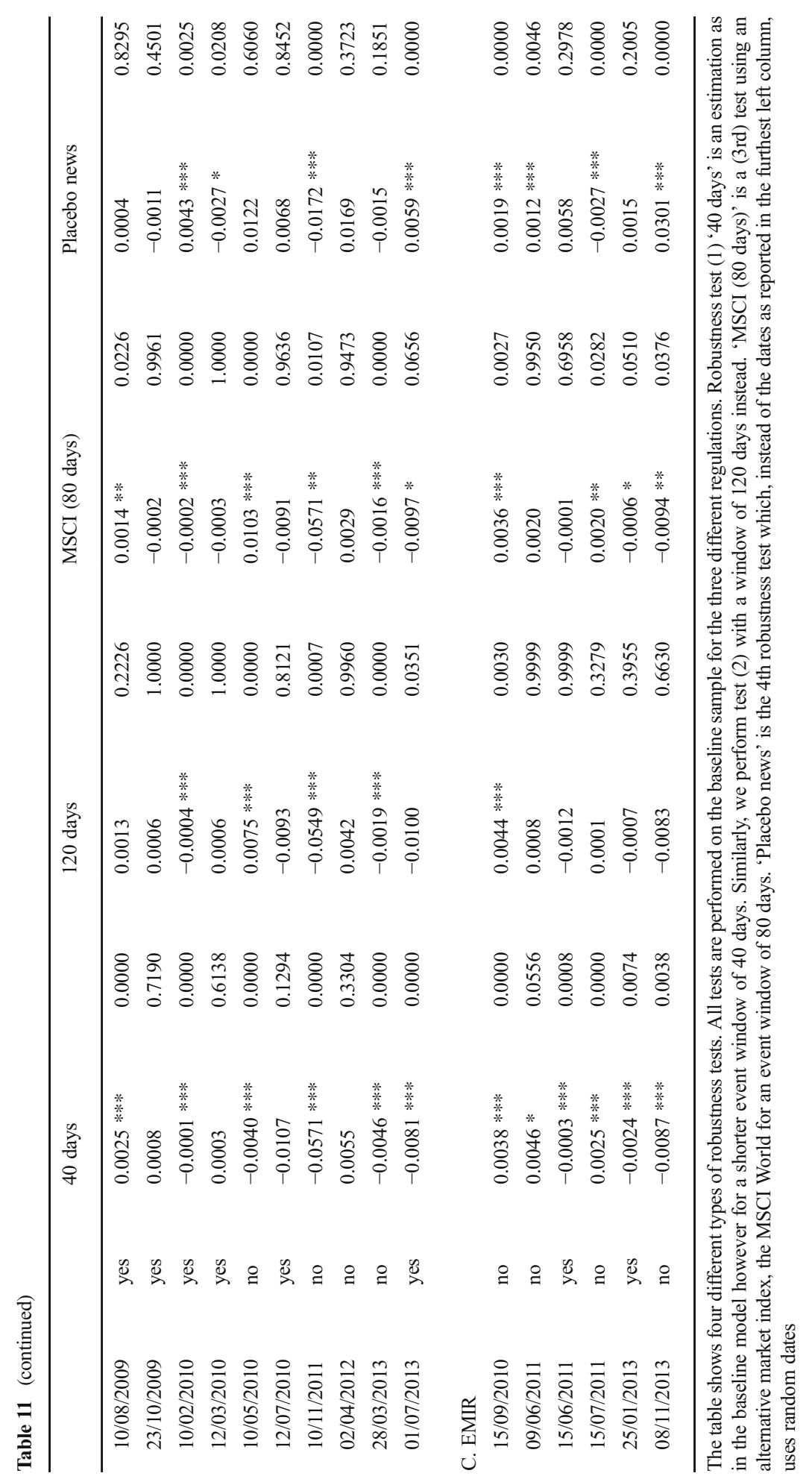




\section{References}

Allen, F., \& Carletti, E. (2013). Systemic risk from real estate and macro-prudential regulation. International Journal of Banking, Accounting and Finance, 5(1/2), 28-48.

Bakk-Simon, K., Borgioli, S., Giron, C., Hempell, H., Maddaloni, A., Recine, F., \& Rosati, S. (2012). Shadow banking in the euro area - an overview. In Occasional paper series 133. Frankfurt: European Central Bank.

Basett, W. \& Blake Marsh, W. (2016). Assessing targeted macroprudential financial regulation: the case of the 2006 commercial real estate guidance for banks. Journal of Financial Stability, forthcoming.

Beck, T., DEMIRguc-Kunt, A., \& Maksimovic, V. (2005). Financial and legal constraints to growth: does firm size matter? Journal of Finance, 60(1), 137-177.

Binder, J. J. (1985). Measuring the effects of regulation with stock price data. RAND Journal of Economics, 16(2), 167-183.

Bongini, P., Nieri, L., \& Pelagatti, M. (2015). The importance of being systemically important financial institutions. Journal of Banking and Finance, 50, 562-574.

Brown, S. J., \& Warner, J. B. (1985). Using daily stock returns: the case of event studies. Journal of Financial Economics, 14(1), 3-31.

Campbell, J. Y., Lo, A. W., \& Mackinlay, A. C. (1996). The econometrics of financial markets. Princeton: Princeton University Press.

Chen, C., So, M., \& Gerlach, R. (2005). Asymmetric response and interaction of U.S. and local news in financial markets. Applied Stochastic Models in Business and Industry, 21(3), 273-288.

Copper, M., Downs, D., \& Patterson, G. (2000). Asymmetric information and the predictability of real estate returns. Journal of Real Estate Finance and Economics, 20(2), 225-244.

Cronin, D., \& McQuinn, K. (2016). Credit availability, macroprudential regulation and the house price-to-rent ratio. Journal of Policy Modelling, 38, 971-984.

Crowe, C., Dell'Ariccia, G., Igan, D., \& Rabanal, P. (2013). How to deal with real estate booms: lessons from country experiences. Journal of Financial Stability, 9, 300-319.

Dean, T., \& Brown, R. (1995). Pollution regulation as a barrier to new firm entry: initial evidence and implications for future research. Academy of Management Journal, 38, 288-303.

Fratianni, M., \& Marchionne, F. (2013). The fading stock market response to announcements of bank bailouts. Journal of Financial Stability, 9(1), 69-89.

Gambacorta, L. (2005). Inside the bank lending channel. European Economic Review, 49(7), 1737-1759.

Georgiadis, G., \& Graeb, J. (2016). Global financial market impact of the announcement of the ECB's asset purchase programme. Journal of Financial Stability. https://doi.org/10.1016/j.jfs.2016.07.009.

Hoesli, M., \& Reka, K. (2013). Volatility spillovers, comovements and contagion in securitized real estate markets. Journal of Real Estate Finance and Economics, 47(1), 1-35.

Kim, T., \& Mangla, V. (2012). Optimal capital regulation with two banking sectors. Working Paper, SSRN.

Kroszner, R. S., \& Strahan, P. E. (2011). Financial regulatory reform: challenges ahead. American Economic Review: Papers and Proceedings, 101(3), 242-246.

Lamdin, D. J. (2001). Implementing and interpreting event studies of regulatory changes. The Financial Review, 53(2-3), 171-183.

McDonald, C., Nixon, T., \& Slawson, C. (2000). The changing asymmetric information component of REIT spreads: a study of anticipated announcements. Journal of Real Estate Finance and Economics, 20(2), 195-210.

Milcheva, S. (2013a). A bank lending channel or a credit supply shock? Journal of Macroeconomics, 37,314 332 .

Milcheva, S. (2013b). Cross-country effects of regulatory capital arbitrage. Journal of Banking \& Finance, 37(12), 5329-5345.

O'Hara, M., \& Shaw, W. (1990). Deposit insurance and wealth effects: the value of being 'too big to fail'. Journal of Finance, 45(5), 1587-1600.

Ongena, S., Smith, D. C., \& Michalsen, D. (2003). Firms and their distressed banks: lessons from the Norwegian banking crisis. Journal of Financial Economics, 67(1), 81-112.

Rice, T., \& Strahan, P. (2010). Does credit competition affect small-firm finance? Journal of Finance, 65(3), 861-889.

Schäfer, A., Schnabel, I., \& Weder di Mauro, B. (2015). Financial sector reform after the subprime crisis: has anything happened? Review of Finance, forthcoming. https://doi.org/10.1093/rof/rfu055.

Schipper, K., \& Thompson, R. (1983). Evidence on the capitalized value of merger activity for acquiring firms. Journal of Financial Economics, 11(1-4), 85-119. 
Schleifer, A., \& Vishny, R. (2011). Fire sales in finance and macroeconomics. Journal of Economic Perspectives, 25(1), 29-48.

Schwert, G. W. (1981). Using financial data to measure effects of regulation. Journal of Law and Economics, 24(1), 121-158.

Sing, T. F., Tsai, I.-C., \& Chen, M.-C. (2016). Time-varying betas of US REITs from 1972 to 2013. Journal of Real Estate Finance and Economics, 52(1), 50-72.

Smales, L. (2015). Asymmetric volatility response to news sentiment in gold futures. Journal of International Financial Markets, Institutions and Money, 34, 161-172.

Tsai, I.-C., Lee, C.-F., \& Chiang, M.-C. (2012). The asymmetric wealth effect in the US housing and stock markets: evidence from the threshold cointegration model. Journal of Real Estate Finance and Economics, 45(4), 1005-1020.

Veronesi, P., \& Zingales, L. (2010). Paulson's gift. Journal of Financial Economics, 97(3), 339-368.

Williams, C. (2015). Asymmetric responses to earnings news: a case for ambiguity. The Accounting Review, $90(2), 785-817$.

Zellner, A. (1962). An efficient method of estimating seemingly unrelated regressions and tests for aggregation bias. Journal of the American Statistical Association, 57, 348-368. 